\title{
Celal Esad'a (Celal Esat Arseven) Göre Osmanlı Dönemi Belediyelerinde Arşiv Çalışmaları: İstanbul Şehremaneti (Belediyesi) Örneği
}

\section{Archival Studies in the Municipalities of the Ottoman Period according to Celal Esad (Celal Esat Arseven): The Case of the Municipality of Istanbul}

\author{
İshak Keskin ${ }^{1}$ (1), Sinan Sümbül ${ }^{1}$
}

'İstanbul Üniversitesi, Edebiyat Fakültesi, Bilgi ve Belge Yönetimi Bölümü, İstanbul, Türkiye

ORCID: İ.K. 0000-0003-1611-1330; S.S. 0000-0002-7107-8927

Sorumlu yazar/Corresponding author: İshak Keskin (Prof. Dr.),

İstanbul Üniversitesi, Edebiyat Fakültesi, Bilgi ve Belge Yönetimi Bölümü, İstanbul, Türkiye E-posta: ishak.keskin@istanbul.edu.tr

Bașvuru/Submitted: 16.11.2020 Revizyon Talebi/Revision Requested: 08.12.2020 Kabul/Accepted: 18.12 .2020

Online Yayın/Published Online: 31.12 .2020

Atıf/Citation: Keskin, İ., Sümbül, S. (2020) Celal esad'a [celal esat arseven] göre osmanl dönemi belediyelerinde arşiv çalışmaları: istanbul sehremaneti (belediyesi) örneği. Bilgi ve Belge Araştırmaları Dergisi, 14, 1-41. http://doi.org/10.26650/bba.2020.14.01

\section{ÖZ}

Arşivcilik mesleği hakkında kaleme alınan eserler; mesleğin tarihsel gelişme süreci, mevcut durumu ve -fütüristik bir yaklaşımla- gelecekte ne türden gelişmeler olabileceği hakkında bilgiler verir. Türk tarihinde arşivcilik konusuna hasredilmiş eserlerin sayısı oldukça az olmakla birlikte olanlar da gün yüzüne çıkarılmayı beklemektedir. Celal Esad [Arseven] tarafindan kaleme alınan "Belediyelerde Evrâkın Kayıd Ve Tasnîfi Nasıl Olmalıdır" adlı eser, arşivcilik konusuna değinen nadir örnekler arasındadır. Bu eser, 20. yüzyıl Osmanlı yerel yönetimlerinde arşivcilik konusunu İstanbul Şehremaneti (İstanbul Belediyesi) özelinde değerlendirmektedir. Söz konusu eserde; Osmanlı yerel yönetimlerinde büro yönetimi, kayıt, dosyalama, koruma, düzenleme ve arşiv işlemlerinin önemi ve nasıl olması gerektiği konuları örnekleriyle birlikte incelenmişstir. Bu araştırma, adı geçen kitabın zamanın yerel yönetimleri bakımından öneminin değerlendirilmesi ve günümüz gelişmeleriyle karş̧laştırılması amacıyla hazırlanmıştır. Celal Esad'ın bu eseri, kayıt, dosyalama ve düzenleme gibi birçok belge yönetimi fonksiyonunun o dönem de var olduğuna ve uygulandığına işaret etmektedir. Araştırmanın deseni durum çalışmasıdır. Verilerin değerlendirilmesi ise içerik analizi tekniği ile gerçekleştirilmiştir. Anahtar kelimeler: Osmanlı İmparatorluğu, Celal Esad (Celal Esat Arseven), İstanbul Belediyesi (Șehremaneti), yerel yönetimler, arșivcilik, belediye arșivleri

\section{ABSTRACT}

Works on the archival profession provide information on the historical development of the profession, on its current case, and -looking from a futuristic perspective- on its possible future developments. There are few works devoted exclusively to the subject of archival studies in Turkish history and those available are still waiting to be brought to daylight. The book entitled How Should Documents Be Recorded and Classified in Municipalities by Celal Esad [Arseven] is among the few works on archival studies. It examines the subject of archival activities in the 20th Century Ottoman municipalities, focusing particularly on the Municipality of Istanbul. It focuses on the subjects of office management, registration, filing, protection, organization, and archival practices in the Ottoman municipalities by giving examples while also emphasizing their significance and defining how they should be performed. The aim of this article is to evaluate the significance of the said book with respect to the municipalities of its age and to compare it with the current developments. Celal Esad's book reveals that many document management functions such as registering, filing and organizing were also available and practiced at the time the book was written. This article was designed as a case study while the data evaluation was carried out through the technique of content analysis. Keywords: Ottoman Empire, Celal Esad / Celal Esat [Arseven], The Municipality of Istanbul, Istanbul Municipality Kadıköy Department, municipalities, archival studies, municipal archives 


\section{EXTENDED ABSTRACT}

Works on the archival profession provide information on the historical development of the profession, on its current case, and -looking from a futuristic perspective- on its possible future developments. There are few works devoted exclusively to the subject of archival studies in Turkish history. The book entitled How Should Documents Be Recorded and Classified in Municipalities by Celal Esad [Arseven] is among the few works on that subject. Although this work, which was written in Ottoman Turkish by Celal Esad, a versatile intellectual figure of the Ottoman period and of the period of the Turkish Republic, dates back to a century ago, its content is still significant today. It examines the subject of the archival activities in the 20th Century Ottoman municipalities by focusing particularly on the Municipality of Istanbul. The book focuses on the subjects of office management,document registration, filing, protection, organization, and archival practices in the Ottoman municipalities by giving examples while also emphasizing their significance and defining how they should be performed. The aim of this article is to evaluate the significance of the book entitled How Should Documents Be Recorded and Classified in Municipalities with respect to the municipalities of its age and to compare the book with the current developments in the field. It provides a content analysis of the said book and presents a detailed discussion of the basic archival issues that the book informs its readers about. Another aim of the article is to investigate which sub-topics this book deals with within the framework of the basic issues such as office and record management as well as institutional archival practices and loan procedures.

The book entitled How Should Documents Be Recorded and Classified in Municipalities was written, as the writer himself said, in order to give information on the procedures of registering and protecting documents as well as archival practices and loan procedures of documents in municipalities. The main subject of the book comprises the archival activities performed in municipalities. The book focuses on the archival activities that belong to a particular type of institution. This book, which -due to its size- should rather be considered as a treatise, was written basically on the records and the archive produced in the Municipality of Istanbul as well as on the office and archival storage activities there. This book is one of the most extensive books on the archival activities in the Ottoman period. Although the file examples given in the book were prepared for the Municipality of Kadıköy in particular, they contain some basic features that can function as an example for other municipalities as well.

The introductory sections of the book focus on the procedures of registering and protecting documents and, consequently, on the significance of archives. The book, in general, provides detailed information on the procedures of registering, protecting, organizing, and filing the documents produced in the offices as well as the procedures of transfering those documents to the archive, the archival processes, and procedures of loan requests from the archive. The writer presents five basic chapters in the book about the recording, office procedures and 
archival procedures of documents. However, there are also some noteworthy basic sub-topics. The book consists of 29 pages in total while the emphasis is openly put on the fourth section (9 pages). The least emphasized chapter, on the other hand, is the fifth chapter ( 3 pages in total). The writer discusses in his book subjects like the qualities of the clerks who perform the practices; the titles, rights, responsibilities and qualities of those clerks; the professional terminology, the material used as well as how the secretarial work and the office and archival practices should be carried out. The third section of this article, where the book is analysed, follows the divisions and chapter headings made by the writer himself. However, the article divides the information given under the headings of the book into sub-sections in relation to their professional concerns. There are, in the book, sample forms for various procedures, the layout plan for the recording and archival clerks as well as the management, and the logo designed for the Municipality of Istanbul.

At the end of this article, a glossary is given in order to explain the concepts used in the book for the subjects related to the filing department, offices, archives and management. These concepts have been given in their original spelling and they have been explained based on their meanings in the book.

This book by Celal Esat Arseven analysed here in this study, shows that the profession and procedures of record management, which have generally been accepted to have started in the post-Second World War period, had actually already begun in the late Ottoman period institutions. This shows openly that the Turkish record management tradition in the modern sense started before the Turkish Republic. This book shows once more that there really are genuine treasures which will bring to the daylight an immensely remarkable state tradition and civilisation hidden among the dusty shelves of history.

This research presents a case study which focuses on the data based only on a single work by Celal Esad through the technique of content analysis. It examines what the office and archival procedures were like in an Ottoman institution (the Municipality of Istanbul) based on the data obtained from the book entitled How Should Documents Be Recorded and Classified in Municipalities. It also finds out information on the concepts used at the time when that book was written, on the authorized officials, the equipment used and the procedures carried out. It presents a comparison of the information obtained with the current archival practices. Thus, it aims to fill a significant gap by providing researchers with a comparative example about the historical development of the archival profession. 


\section{GİRIŞ}

Belediyelerde Evrâkın Kayıd Ve Tasnîfi Nasıl Olmalıdır? adlı eser, tarihin tozlu raflarına gizlenmiş muhteşem bir devlet gelenek ve medeniyetini gün yüzüne çıkaracak gerçek hazinelerin yaşamakta olduğunu gözler önüne sermektedir.

Arşivciliğin teorik, pratik ve kurumsal yönleriyle anlaşılmasını sağlayan ve doğrudan arşivcilik mesleğini ilgilendiren eserlerin yazılması tarih içinde eskiye dayanan bir gelişme değildir. Bunların ilk örneğine -mevcut araştırmalar doğrultusunda- 12. yüzyıl İslam dünyasında rastlamak mümkündür. Bu ilk örnek, İbnüssayrafi tarafından kaleme alınan -ve tarihçilere göre bir (Fâtımî) teşkilat tarihi kitabı olarak nitelendirilen- El-Kânûn fî Dîvâni’r-Resâil başlığını taşıyan eserdir (İshakoğlu, 2009, s. 224-243). Eserde; yazı işleri bürosunun kayıt tutma şeklinin anlatılması yanında kâtibin ve arşivcinin iş yükünün özellikleri ve mesleki niteliklerine dair bilgilere de geniş şekilde yer verilmektedir. Bu yüzden söz konusu eser, arşivciler arasında arşivcilik tarihi içinde hazırlanan "ilk mesleki el kitabı” olarak ün kazanmıştır. Bu el kitabının iki bölümü doğrudan kitabet (yazı işleri) bürosundaki kayıt memurlarının (kâtipler) ve arşivcilerin (hâzin) nitelikleriyle ilgilidir (Posner, 1998, s. 27-28). İbnüssayrafi'nin söz konusu eserinin önemi ise kâtiplerin ve arşivcilerin "mesleki rolleri” ve tarihte bilinen ilk yazılı "iş tanımları"nın açıklanmasından ileri gelmektedir (Posner, 1972, s. 25-26).

Arşivcilik mesleğine ilişkin eserlerin mevcudiyeti Avrupa tarihinde 16. yüzyılda başlar. Bu yüzyıldan itibaren de nispeten hızlı bir şekilde artmaya başladığı görülür. Jakob von Ramingen (1510-1582), Baldassarre Bonifacio (1585-1659), Ahasver Fritsch (1629-1701), Georg Aebbtlin (1620-1687), Veit Ludwig von Seckendorf (1626-1692), Jean Mabillon (1632-1707), Philipp Ernst Spiess (1734-1794), Karl Friedrich Bernhard Zinkernagels (1759-1838), Josef Anton Oegg (1762-1817), Franz Xaver Bronne (1758-1850) gibi isimler ve yayınları, arşivcilikle ilgili yayıncılığın ilgili dönemde iyice arttığını açıkça göstermektedir. İlerleyen tarihlerde ise arşivcilik konusundaki süreli yayınların yayın hayatına başlaması ayrıca söz konusu olmuştur (Rumschöttel, 2008, s. 11-29; Keskin, 2008/a, s. 5-7). Bu duruma karşın, şimdiye kadar yapılan literatür taramalarından anlaşıldığı kadarıyla, Türk kültüründe arşivciliği doğrudan konu alan bir çalışmanın erken dönemlerde yapılmamış olduğunu belirtmek gerekmektedir.

Osmanlı dünyasında ancak 20. yüzyılın başlarında arşivciliği konu alan birkaç eserin kaleme alınmış olduğu bilinmektedir. Diğer bazı kaynaklarda ise eser içinde arşivcilikle kısmen ilgilenildiğini gösteren bilgiler mevcuttur. Eser içerisinde arşivcilik konusuna kısmen temas edilmiş olanlara Hayreddin Nedim [Göçen] tarafından kaleme alınan Vesâik-i Târîhiyye ve Siyâsiyye Tetebbuâtı (Hayreddin, 1326; Hayreddin Bey, 2008) başlığını taşıyan eser örnek gösterilebilir. Bu kaynakta; metnin geneli içine serpiştirilmiş şekilde arşivcilik mesleği ile doğrudan ve dolaylı olarak ilişkili görülebilecek bazı konular yer almaktadır. Bu eser, iki ayrı çalışmaya konu olmuştur (Keskin, 2008/b, s. 289-306; Keskin ve Günalan, 2011, s. 332-353). 
Bu çalışmalardan ancak rapor niteliğinde olan bir diğeri de Evrâk-ı Atîkanın Sûret-i Tasfiyesine Dâir Rapor başlığını taşıyan çalışmadır (Mehmed Hayati ve Osman Nuri, 1332; Anameriç ve Rukanc1, 2006, s. 91-111) ve bütünüyle arşivciliğin içinde üç alt konu (depo, ayıklama, imha) ile ilgilenmektedir. Bu çalışma; 1911-1914 (1327-1330) yılları arasında İstanbul'da kamuya ait çeşitli arşiv depolarında bulunan evrakın ayıklanması ve imhası çalışmaları çerçevesinde hazırlanmıştır.

$\mathrm{Bu}$ çalışmalardan sonuncusu -ve bu makaleye konu olan- ise Celal Esad [Arseven] tarafından kaleme alınan ve bir kurum türüne yönelik arşiv çalışmalarıyla ilgilenen eserdir. Bu eserin merkezinde belediyelerde yapılan arşiv çalışmaları yer almaktadır. Daha çok -kısalığı nedeniylerisale özelliği taşıyan bu eser, Belediyelerde Evrâkın Kayıd ve Tasnîfi Nasıl Olmalıdır? başlığını taşımaktadır. İstanbul Şehremanetinde üretilen kayıtlar ve oluşturulan arşiv ile buradaki büro ve arşiv deposu faaliyetleri temel alınarak yapılan bu çalışma, Osmanlı döneminde yazılmış -muhtemelen- en kapsamlı arşiv çalışmalarından birini oluşturmaktadır. Eserde verilen dosyalama örnekleri ise Kadıköy dairesi/şubesi özelinde hazırlanmıştır ve diğer şubeler için de örnek teşkil edebilecek temel özellikler taşımaktadır.

Celal Esad, eserinde önerdiği “" [...] kayıt ve tasnîfin [...] belediyelere sûret-i tatbîkinden [...]" bahsetmektedir. Bununla birlikte yazar, kendisi tarafından açıklanan kayıt ve düzenleme işlemlerine ilişkin yöntemlerin "[...] bazı tadilât ile her idâreye tatbîk [...]” olunabileceği; ancak diğer kurumlar bir yana belediyelerde dahi kurumsal işlemlerin yoğunluğuna bağlı olarak " [...] bazı cihetlerin tebdîli icâb" edeceği düşüncesindedir. Yazar, bu yöndeki sözlerini şu şekilde tamamlamaktadır: "Binâenaleyh evvelâ İstanbul Belediyesini teşkîl eden şehremânetine göre şâyân-1 tatbîk bir usûlden bahsetmeyi münâsib görüyoruz. Aynı usûl, teferruâtında bazı farklarla devâir-i beledîyeye ve taşra belediyelerine dahi kâbil-i tatbîkdir.” (Celal Esad, 1331/1915, s. 5).

$\mathrm{Bu}$ araştırmaya konu olan Belediyelerde Evrâkın Kayıd ve Tasnîfi Nasıl Olmalıdır? adlı eser toplam 29 sayfadan oluşmaktadır ve -müellif tarafından- beş bölüme ayrılması uygun görülmüştür. Eserin ilk iki sayfası iç kapak bilgisine ve bunu müteakip boş bırakılan bir sayfaya ayrılmıştır. Eserin metin kısmı 3.-29. sayfaları arasında yer almaktadır. Eserin "Belediyelerde Evrâkın Kayd ve Tasnîfi” başlığını taşıyan birinci bölümü 3.-7. sayfalar arasında; "Kayd-1 Ulûmî Muâmelâtı" başlığını taşıyan ikinci bölümü 7.-15. sayfalar arasında; "Şûbelerde Kayd Muâmelâtı" başlığını taşıyan üçüncü bölümü 15.-18. sayfalar arasında; "Mahzen-i Evrâk" başlığını taşıyan dördüncü bölüm 19.-27. sayfalar arasında ve "Mahzen-i Evrâkdan Evrâk Talebi” başlığını taşıyan beşinci bölüm de 27.-29. sayfalar arasında yer almaktadır. Eserin bölümleri arasındaki ağırlık açık şekilde dördüncü bölüme (9 sayfa) verilmiştir. Eserde en az yer işgal eden bölüm ise son bölümdür (toplam 3 sayfa -metin kısmı bir sayfadan az fazla ve bir de form örneği verilen sayfa-). Günümüz bakış açısı ile eserin giriş kısmı ve iki bölümden oluşması mümkündür. Eserin giriş kısmında "Kayd ve Hıfz-1 Evrâkın Lüzûm ve Ehemmiyeti”, "Muntazam Usûl-i Kayd ve Tasnîfin Tatbîkindeki Müşkülât”, "Kâğıtların Hacim ve Şeklinde 
Ittırâd" konularından; "Belediyelerde Evrakın Kayd ve Tasnifi” başlığını taşıyacak birinci bölümde "Kayd-1 Umûmi Muâmelâtı" ve "Şûbelerde Kayd Muâmelâtı" alt başlıklarından; "Mahzen-i Evrâk" başlığını taşıyacak ikinci bölüm ise "Tasnîf ve Hıfz-1 Evrâk Muâmelâtı" ve "Mahzen-i Evrâkdan Evrâk Talebi” alt başlıklarından oluşabilirdi. Ancak bu çalışmamızda ideal başlıklandırma yerine, müellifin bölümlemesi (başlıklandırması) dikkate alınmış ve çalışmamızın üçüncü ana başlığı müellifin eserini bölümlemesi esas alınarak şekillendirilmiştir. Bu başlığın üçüncü düzey alt başlıkları ise tarafımızdan oluşturulmuştur. Müellif, bunlardan başka -verdiği bilgilerin muhtemelen daha iyi anlaşılmasını ve uygulanmasını temin içineserinde onbir form, dört resim ve bir de kroki kullanmayı tercih etmiştir.

Belediyelerde Evrâkın Kayıd ve Tasnîfi Nasıl Olmalıdır? başlı̆̆ını taşıyan kitap, daha önce basit transkripsiyon tarzında bir makale (Sümbül ve Keskin, 2018, s. 23-47) ve sadeleştirme şeklinde bir de kitap (Sümbül ve Keskin, 2020, s. 100-129) olmak üzere iki ayrı çalışmaya konu olmuştur. Ancak bu çalışmaların hiçbirinde söz konusu eserin hangi arşiv temalarına ilişkin bilgi verdiği konusu başlıklar halinde ve ayrıntılı bir şekilde ayrıca analiz edilerek ortaya konulmamıştır. Zaten bu durum, söz konusu çalışmaların odağında da değildir. Elinizdeki bu çalışma ise Celal Esad tarafından -Kadıköy Belediye Dairesi Müdürü olduğu sıralarda- kaleme alınan bu risalenin/kitabın içerik analizinin yapılması ile oluşturulmuştur. Böylelikle ilgili çalışmanın hangi temel arşivsel konulara ilişkin bilgi verdiği konusu da detaylı bir şekilde tartışılmıştır. Dolayısıyla bu çalışmanın amacı, adı geçen kitapta büro ve belge yönetimi ile kurumsal arşiv işlemleri ve ödünç işlemleri gibi temel konular çerçevesinde hangi alt konulara değinildiğinin araştırılmasıdır. Çalışmanın sonunda ayrıca, bir kavramlar listesi ilave edilmiştir. Bu kavramlar listesi, eser içinde kayıt, büro, arşiv ve idari işler konusunda kullanılmış olan kavramlardan oluşmaktadır. Kavramlar, eser içinde sahip oldukları anlam göz önünde bulundurularak açıklanmıştır. Bu kavramların yazılışlarında dönemin imlası temel alınmıştır. Bu araştırma eserin yazıldığı dönemdeki bir belediye örneğinde belge yönetimi iş ve işlemlerinin nasıl yürütüldüğü açıklanarak durum çalışması yapılmış ve Celal Esad'ın sadece bir eserine dayanan veriler içerik analizi tekniği ile değerlendirilmiştir. Eserde verilen bilgiler ayrıca günümüz arşivcilik uygulamaları ile karşılaştırılmıştır.

\section{Celal Esad Hakkında Kısa Bir Biyografik Bilgi}

Osmanlı ve Cumhuriyet dönemlerinde yaşamış olan Celal Esad, bir sadrazam ailesine mensuptur. Sadrazam Ahmed Esad Paşa'nın (1828-1875) oğlu olarak İstanbul'da dünyaya geldi (1875). İlk, orta ve lise eğitimini Beşiktaş’ta (Taşmekteb ve Beşiktaş İbtidâîsi), (bir yıl kadar) Galatasaray Sultanisinde, ardından Beşiktaş Askeri Rüşdîyesinde tamamladı. 1889 yılında Mekteb-i Mülkîyeye kaydoldu, sonra resim kabiliyeti dolayısıyla aynı zamanda Sanâyî-i Nefîse Mektebine devam etti (Yazıc1, 2009, s. 572). 1891 yılında Mekteb-i Harbîyenin 'zâdegân' sınıfına yazıldı (1891); buradan mezun olduktan sonra, bir subay ve hünkâr yaveri olarak askerlik mesleğine intisap etti. 
II. Meşrutiyet'ten (1908) kısa bir süre önce askerlik mesleğinden ayrılan Celal Esad, 1912 yılında Galata' daki binaların tespit ve kayıt işlemlerinden sorumlu Tahrîr-i Musakkafât Reisliğine tayin olundu. 1920-1941 yılları arasında belediyecilik, şehircilik ve mimarlık tarihi derslerini okuttuğu Sanâyî-i Nefîse Mektebinde eğitimci olarak görev aldı. 1923’ten sonra kısa sürelerle Dârülbedâyi Müdürlüğü ile İstanbul Ticaret Odası Neşriyat Müdürlügüü görevlerini birlikte yürüten Celal Esad, Ankara'nın imar planını hazırlamak üzere iki yıl süre ile görevlendirilen Alman şehircilik uzmanı Hermann Jansen'in yanında Ankara sınâi müşaviri olarak hizmet gördü. VII. (1943-1946, İstanbul) ve VIII. dönem (1946-1950, Giresun) milletvekili olarak Türkiye Büyük Millet Meclisinde görev yapt1. 1951-1958 y1lları arasında ve istifa etmek suretiyle ayrılana değin Gayri Menkul Eski Eserler ve Anıtlar Yüksek Kurulu üyesi ve bir süre de bu Kurulun başkanı olarak bürokraside görev almaya devam etti (Eyice, 1991, s. 398).

Çalışma hayatıyla beraber yayın hayatına da başlayan Celal Esad, ömrü boyunca edebiyat (piyes ve roman), müzik, hatırat, belediyecilik, kütüphanecilik ve arşivcilik, sanat (genel sanat tarihi, Türk sanat tarihi, resim sanatı ve modern sanat), şehircilik ve İstanbul gibi konularda otuzun üzerinde eser kaleme aldı (Sümbül ve Keskin, 2018, s. 24-26; Sümbül Keskin, 2020, 12-15). II. Meşrutiyet'in ilanından (1908) hemen sonra Paris'e giden Celal Esad, burada bulunduğu yıllarda arkadaşı Sâlah Cimcoz ile birlikte 'Kalem' adında bir dergi çıkardı, İstanbul'a döndükten sonra İstanbul tarihi ve eski eserlere dair kitaplar kaleme aldı, Birinci Dünya Savaşı yıllarında (1914-1918) belediyecilikle ilgili kitaplar yazdı (Eyice, 1991, s. 398).

Celal Esad, yayın faaliyetleri ile beraber Türk kültürünün gelişmesine hizmet etmiş değerli bir bilim insanı, kıymetli bir sanatkâr ve meşhur bir yazar olarak 1971 yılında vefat edene kadar ilmi çalışmalarını sürdürdü (Diyarbekirli, 1972, s. 31). 13 Kasım 1971 günü vefat eden Celal Esad, Sahra-i Cedid mezarlığına defnedildi (Eyice, 1972, s. 178). Doğum tarihi itibarıyla soyadı bulunmayan Celal Esad, 1934 yılında çıkarılan Soyadı Kanunu'ndan sonra Arseven soyadını aldı ve 'Esad' ismi de Türkçedeki yeni yazım kuralları gereği 'Esat' şeklinde telaffuz edilerek yazılmaya başlandı (Sümbül ve Keskin, 2018, s. 24).

\section{Belediye Arşivleri ve Önemi}

Hem devlet tüzel kişiliği hem de yazının icadıyla doğrudan ilişkili olan arşiv oluşturmanın beş bin yılı aşan uzun bir geçmişi vardır. Ebla, Mari, Amarna, Hattusas, Ugarit ve Pylos (Navarin) gibi devlet-şehir devletlerinin arşivleri bunun için değerli örnekler sunmaktadır (Keskin, 2007/a). Devlet-şehir devletlerinin arşivleri örneğinde olduğu gibi bir kamu arşiv türü olarak belediye arşivlerinin, -günümüz örnekleriyle fazla paralellik göstermese de- uzun sayılabilecek bir geçmişi vardır. Eski Mısır ve Grek medeniyetlerinde faaliyet gösteren örnekleri bunun açık delilleridir. Eski Mısır'ın Theb, Heliopolis, Nanaion, Mendes-Thmouis, Arsinoite, Memphis ve Tebtinus şehirleri (Keskin ve Kutluoğlu, 2013/a) ile Atina'nın (Bouleterion) ve diğer Helen şehirlerinde faaliyet gösteren şehir konseylerinin faaliyetleri sonucu üretilen 
kayıtların korundukları arşivler (Keskin ve Kutluoğlu, 2013/b), bir taraftan merkezi kamu hizmetlerine bir taraftan da yerel hizmetlere ilişkin kayıtların korundukları mekânlardı. İlerleyen zamanlarda da bu türden arşivlerin var olduğu bilinmektedir.

Yerel yönetimler belde, ilçe, il gibi belirli bir coğrafi alanla ve bu alan içinde yaşayan bir toplulukla ilişkilidir. Bu topluluğu ilgilendiren hususlarda hizmet yerine getirmek için kurulur; karar (ve bazen de yürütme) organları yerel topluluk tarafindan seçim yoluyla yetkilendirilir. Söz konusu yönetimlerin görevleri ve yetkileri ile özel gelirleri yasalarla belirlenir. Yerel yönetimler, kendilerine ait bütçeye ve personele sahiptir (TODAİE, 1992, s. 1-2; aktaran: Çiçek ve Bozlağan, 2008, s. 193). Temelde şehirlerin yönetilmesinde faaliyet gösteren ve bir kamu tüzel kişisi olan yerel yönetimler, sahip olduğu mali kaynakları kendi organlarının kararları doğrultusunda ve faaliyetleri sırasında kullanan özerk bir sosyal-mali-idari yapıdır. Bu sosyalidari yapı; geç Ortaçağ Avrupası'nın ürünü olarak 12. yüzyıl Avrupa'sında başlayan ve etkileri bugüne kadar uzanan bir tarihi gelişme olarak bilinir (Ortayl1, 1992, s. 398; Hildesheimer, 1997, s. 109).

Belediyeciliğin ve belediye arşivlerinin nasıl geliştiği hakkında bir örnek olarak Fransa'dan özellikle söz edilebilir. Fransa' da belediyecilik faaliyetleri, -diğer Ortaçağ Avrupası gelişmeleri gibi- 12. yüzyılda görülen bir durumdur. Konu hakkındaki ilk bilgiler Abbé (Papaz) Saint Germain des Prés'ye aittir. Abbé, 9. yüzyılda kaleme aldığı bir yazısında «maior» tabirini ilk kullanan kişi olmuş ve maior'ü köylerde senyör adına idarecilik yapan kimse olarak tanımlamıştır. Maior'un görevleri ise beldenin ekonomik hayatını düzenlemek, temizlik işlerini yürütmek ve güvenliğini sağlamaktı. Bu görevleri daha çok güçlü ve zengin aileler üstlenirdi. 15. yüzyılda ise Yüzyıl Savaşları'nın (1337-1453) da etkisiyle belediye başkanlığı iki yıllığına senyörden satın alınan bir göreve dönüşmüştür. Belediye başkanlarının göreve gelme şekli 17. yüzyılın sonlarında değişmiş, satın alınarak göreve gelme usulü terk edilmiş ve bu defa senyörler tarafından tayin edilerek göreve gelme usulüne dönüşmüştür. İlk belediye arşivleri (Fr. archive municpale; İng. municipal archives) de, -muhtemelen bu gelişmelere bağlı olarak- 1770’de teşekkül etmeye başlamıştır. Bu arşivlerde başlangıçta, yerel hayatın imar, güvenlik ve temizlik hizmetleri ile ekonomi konularına ilişkin belgeler korunmuştur (Hildesheimer, 1997, s. 109).

Belediye başkanlarının senyörler tarafından tayin edilmesi usulü Fransız İhtilali’nden (1789) sonra terk edilmiştir. Çıkarılan 26 Ekim 1790 tarihli bir kanunla belediye başkanları iki yıllığına seçimle işbaşına gelen görevliler olmuşlardır. Bu gelişme göreve gelme usulünün değişmesinin yanı sıra belediye arşivlerinde biriken belgelerin profilini de önemli ölçüde genişletmiştir. Bu tarihten önce yerelin imar, güvenlik, temizlik hizmetleri ve ekonomik hayatına ait belgelerin biriktirildiği ve korunduğu belediye arşivlerinde, -İhtilal sonrası gelişen laik tutum sebebiyle- evlilik, medeni durum, vaftiz, doğum kayıt belgeleri ve kilise tarafından idare edilen arazilerle ilgili belgeler de korunmaya başlamıştır. Buna neden olan daha üst 
gelişme ise Fransız İhtilali sonrasında -devlet idaresinde görülen diğer köklü değişiklikler gibi- Kilise yönetimlerine karşı gelişen resmi tutumdur. Kilise yönetimlerine karşı gelişen laik tutum, kiliselere ait birçok faaliyeti belediye yönetimlerine havale etmekle kalmamış aynı zamanda sonlandırılan faaliyetlere ilişkin önceki kayıtların da belediye arşivlerine verilmesini beraberinde getirmiştir. Bu itibarla evlilik, medeni durum, vaftiz, doğum kayıt belgeleri ve kilise tarafından idare edilen arazilerle ilgili belgeler 26 Ekim 1790' da çıkarılan yasa sonucunda belediyelere (belediye arşivlerine) devredilmiştir. Böylece belediye arşivlerinin belgesel varlı̆̆ arttırılmış, görevleri güçlendirilmiş, arşivi de bu yeni duruma göre düzenlenmiştir. 20 Eylül 1792 tarihli kanunla Kilise'ye ait bütün kayıtların (registres Paroissial) idaresi belediye arşiv idarelerin tarafından üstlenilmiştir (Hildesheimer, 1997, s. 109).

İçinde bulunduğumuz Türk-İslam medeniyet sahasında belediye teşkilatının temelini (sonradan muhtesib olarak anılan) hisbe şeklinde ifade edilen kurum oluşturur. Hisbe teşkilatı, İslam şehrinde haram olanın işlenmesini önlemek üzere teşekkül ettirilen ve zamanla şehirde önleyici kolluk hizmetinin gelişmesini beraberinde getiren bir kamu otoritesi olmuştur (Kallek, 1999). Osmanlı İmparatorluğu'nda "ihtisab ağası" veya "ihtisab emini” denilen muhtesib, kadı tayin edilen her yerde onun yardımcısı durumundaydı. 1826 yılında çıkarılan İhtisab Ağalığı Nizamnamesi ile bu kurumun adı İhtisab Nezaretine, ihtisab ağasının unvanı da ihtisab nazırına çevrildi (Osman Nuri [Ergin], I, 1922/1338, s. 335-361; Kazıcı, 1992, s. 144; Ortayl1, 1992, s. 399). İlerleyen zamanlarda sorumluluk sahası genişleyen İhtisab Nazırlığı, 25 Temmuz 1855 tarihinde kaldırıldı ve görevleri de yeni kurulan şehremaneti (belediye) makamına devredildi (Kazıcı, 1992). Kırım Savaşı'nın (1853-1856) İstanbul'da meydana getirdiği olağanüstü göç hareketliliğinin düzene koyulması amacıyla 1854 yılında İstanbul Şehremaneti kuruldu. Bunu, Galata ve Beyoğlu'nu içine alan bir sahada beledi hizmetlerin görülmesi için -Paris örneği dikkate alınarak- Altıncı Daire-i Belediyyenin kurulması takip etti. ("Belediye", "daire-i beIediyye", "daire-i belediyye reisi" ve "daire-i belediyye meclisi" kavramları ve unvanları da ilk defa Galata-Beyoğlu Belediyesi için kullanıldı.) Osmanlı taşrasında ise ilk şehremanetleri ticari hareketliliğin arttığı Tuna, Bağdat ve Beyrut gibi liman şehirlerinde kuruldu. 1877 yılında çıkartılan Dersaâdet ve Vilayet Belediye Kanunu ile Osmanlı topraklarındaki belediyeler sosyal-idari-hukuki varlık olmanın yanı sıra bir tüzel kişilik de kazandı (Ortaylı, 1992).

Kamu hizmetlerinin görülmesi sırasında üretilen kayıtlar, -kamu tüzel kişiliğinin yasal yetkileri doğrultusunda üretilmeleri nedeniyle- aynı zamanda kamu arşiv varlığı statüsündedir. Buna bağlı olarak, bir beldeyle alakalı kamu hizmetlerinin yerel bir kamu tüzel kişisi tarafından görülmesi sırasında üretilen belgelerin üreticisi de bir kamu tüzel kişiliğine sahip olan belediyelerdir. Bu özellik de, belediyelerdeki arşivlerin (belediye arşivleri-municipal archives) birer "kamu arşivi", kurum düzeyinde değerlendirme doğrultusunda da "kurum arşivi” niteliğinde olduğu anlamına gelir (Anameriç, 2010/a, s. 8). Bu kavram her büyükşehir, il (ilk kademe), ilçe ve belde belediyeleri için geçerlidir. 
Belediyelerin yerel düzeyde faaliyet gösteren sosyal-idari bir kurum olmaları, sorumluluklarına ve hizmet çeşitliliğine yansımaktadır. Bu sorumluluklar ve geniş hizmet yelpazesi de, bilgi değeri özellikle yerel düzeyde yüksek olan belgelerin üretilmesini, üretilen belgelerin konusal çeşitliliğini ve sayısal miktarını etkiler. Bu durum; kurumsal düzeyde (idari, mali, hukuki) değere sahip çok sayıda belgenin belediyelerde üretilmesini ve araştırma değeri yüksek bir kurum arşivinin -mevzuat gereği- belediyelerde oluşturulmasını sağlar. Zira Türkiye'de ulusal düzeyde yürürlükte olan mevzuat kamu kurumu niteliğindeki örgütlenmeler -dolayısıyla belediyeler- için, açık bir şekilde faaliyetlerin ispatı için delil değeri olan kayıtlar üretmelerini, faaliyetlerinin bir sonucu olarak ürettikleri belgeleri korumalarını, bu kayıtları düzenlemelerini ve erişime açık tutmalarını ve üretilen kayıtların bir kısmını -saklama planları doğrultusundadevlet arşivine (Devlet Arşivleri Başkanlığı) teslim etmelerini emretmektedir (Devlet Arşiv Hizmetleri ..., 2019, m. 16/1-8).

Belediyelerin yükümlülükleri ve hizmet alanları ile ilgili bilgiler belediyeler hakkındaki mevzuatta açık bir şekilde belirtilmektedir. ${ }^{1}$ Belediyeler, bu mevzuat doğrultusunda arşiv çalışmalarını yapmak zorundadırlar. Belediyelerde arşiv iş ve işlemleri Yazı İşleri ve Kararlar Daire Başkanlığı/Müdürlüğü tarafından yerine getirilmektedir (Anameriç, 2010/a, s. 9). Bundan başka, belediyelerin birimleri de -daha sonra kurum arşivine devredilmek üzere- kendilerine ait birim arşivleri oluşturmaktadır (Anameriç, 2010/a, s. 9). Bu birim arşivlerinden gelen evrakın kurum içinde bir noktada toplanması ile de kurum arşivi teşekkül etmektedir.

Belediyeler; Devlet Arşivleri Başkanlığının yükümlüsü durumundadır (Devlet Arşiv Hizmetleri Hakkında Yönetmelik, 2019, m. 9). Söz konusu yönetmelik gereğince belediyeler; kurum-birim arşivi oluşturmakla, arşiv iç-dış alanlarını düzenlemekle (Arşiv Mekanlarının Düzenlenmesi, TS 13212, 2006), sahip olunan evrakın birim ve kurum arşivlerinde erişim, saklama, tasfiye ve Devlet Arşivleri Başkanlığına transfer edilebilecek şekilde tutulmasını sağlamakla yükümlüdür. Yine belediyeler, faaliyetleri doğrultusunda sahip olunan her türlü belgenin kurumsal ve kamusal amaçlar doğrultusunda kullandırmalı, bu belgeler üzerinde gerekli tasfiye ve transfer işlemleri ile bütün evrak, dosya ve arşiv işlemlerini düzenli bir şekilde ve zamanında yerine getirmeli, yazışma ve belge yönetimi ile dosya-saklama planları oluşturmalıdır (Anameriç, 2010/a, s. 10-11). Evrakın belediyelere ait birimler tarafından üretilip devlet arşivine teslimine kadar geçen süre içinde, evrak üzerinde, iç yazışmaları ilgilendiren haberleşme/ yazışma kodları (kurum/birim kodu) ile düzenleme, erişim, koruma ve transfer işlemlerini kolaylaştıran dosya ve saklama planlarına (saklama süreli) ait prosedürlerin standart biçimde

15393 sayılı Belediye Kanunu'nun 14. maddesinde belediyelerin görevleri ve sorumlulukları ve 15. maddesinde belediyelerin yetkileri ve imtiyazları; 5216 sayılı Büyükşehir Belediyesi Kanunu’nun 7.-11. maddelerinde (büyükşehir belediyesinin görev, yetki ve sorumlulukları) belirtilen mahalli hizmetlerin sağlanması sırasında üretilen belgelerin "Devlet Arşiv Hizmetleri Hakkında Yönetmelik”in 1. maddesindeki amaç ve 4. maddenin b-c bentlerindeki içerik ve 5 . maddenin a-b (belgelerin korunması) bentleri, belediyelerin yükümlülüklerinden ve hizmet alanlarından söz etmektedir. 
uygulanması gerekir (Çiçek, 2008; Anameriç, 2010/b, s. 9-10). Belediyeler, bunlardan başka şehir arşivi/şehir belgeliği/kent arşivi/ gibi isimler altında ilgili şehre ait ancak ilgili belediye tarafından doğrudan üretilmeyen ve işlemler neticesinde belediyeye gelmeyen belgelerden oluşan arşivler de kurabilmektedir (Keskin, 2013, s. 603). 1580 sayılı mülga Belediye Kanunu 15. maddesinin 33. Bendi (Belediye Kanunu, 1930, m. 15/33) buna dayanak oluşturmuştur. Bu mülga yasayı kendine dayanak kabul ederek kurulan Çorum Belediyesi Kent Arşivi buna bir örnektir (Keskin, 2013, s. 603).

Sosyal-idari bir kurum olarak belediyeler, hizmet ve vatandaş odaklıdır. Dolayısıyla sorumluluk sahasında yaşayan vatandaşların pek çok yönden ihtiyaçlarının karşılanması işini gerçekleştirirler. Belediyeler, çok farklı idari kademeler tarafindan üstlenilen sağlık, ulaşım, haberleşme, temizlik, eğitim, aydınlatma, su, gaz, çevre ve sosyal alanların düzenlenmesi gibi hizmetleri gerçekleştirirken yoğun bir belge üretimi gerçekleştirir. Belediye arşivlerinin önemi de aslında bundan kaynaklanır. Belediye arşivlerinde bulunan ve idari, hukuki, mali ve araştırma değerlerine sahip bu belgelerden, bir taraftan belediyenin fonksiyon ve faaliyetlerinin gerçekleştirilmesinde karar mekanizmalarının bilgi ve belge ihtiyacını karşılarken, bir taraftan da ilgili kurum ve kişiler ile araştırmacıların bilimsel proje çalışmalarında yararlanılır. Böylelikle araştırma hizmetlerine kaynak temin edilirken, kurumsal hizmetlerin aksamadan yürütülmesi sağlanabilir, belediye hizmetlerinden kaynaklanacak hukuki uyumsuzluk ve anlaşmazlıklar çözülebilir, hizmetler geliştirilip yenilenebilir, makro ve mikro düzeyde kültürel bilgi birikimi korunup aktarılabilir, gerektiğinde akademik, sanatsal, edebi ve kültürel aktiviteler desteklenebilir, kurumsal bilgi yönetimi kurulabilir, kurumsal hafıza korunabilir, şeffaf, sorgulanabilir, adaletli, hesap verebilir ve katılımcı yönetim anlayışı daha kolay bir şekilde yaygınlaştırılabilir (Anameriç, 2010/b, s. 11-12).

\section{Celal Esad Arseven'in Belediye Arşivlerine İlişkin Görüşleri}

Celal Esad, eserini beş ana başlık (bölüm) altında kaleme almıştır. İlk ana başlık (bölüm) "Belediyelerde Evrakın Kayıt ve Tasnifi” adını taşımaktadır. Bu başlık, konuya giriş mesabesinde görülmüş olan üç “derkenar” başlığı ile sınırlandırılmıştır. Bu derkenar başlıkları altında; 1) kayıt ve evrakın korunmasının lüzumu ve önemi, 2) düzenli kayıt usulü ve tasnifin uygulanmasındaki zorluklar ve 3) kâğıtların hacim ve şeklinde birlik (standart) konuları değerlendirilmiştir. İkinci başlıkta (bölüm) "Genel Kayıt İşlemleri”; üçüncü başlıkta (bölüm) "Şubelerde Kayıt İşlemleri”, dördüncü başlıkta (bölüm) “Arşiv (Mahzen-i Evrâk)” ve beşinci başlıkta (bölüm) da "Arşivden Evrak Talebi (Mahzen-i Evrâkdan Evrâk Talebi) konuları ele alınmıştır. Dördüncü başlık (bölüm) altında tasnif ve evrakın korunması işlemleri şeklinde çerçevesi çizilmiş olan sadece bir alt başlık verilmiştir. Aşağıda; yazarın eserini başlıklandırma yöntemine sadık kalınarak, bu başlıklar altında hangi temel mesleki konuların değerlendirildiği üzerinde durulacaktır. Metin içinde harf ( $a, b, c, d$ vs.) biçiminde belirtilen üçüncü derece başlıklar anlamayı ve analizi kolaylaştırmak için tarafımızdan oluşturulmuştur. 


\subsection{Belediyelerde Evrakın Kayıt ve Tasnifi}

\subsubsection{Kayıt ve Evrakın Korunmasının Lüzumu ve Önemi}

Bu bölümde yazar; arşivlerin idari ve ticari faaliyetlerin yürütülmesindeki rolü, arşivlerin kurumsal hafiza olmasındaki önemi, iyi bir kayıt ve evrak koruma yöntemine sahip olmanın faydaları, kurumsal devamlılığa arşivin katkısı, arşivin medeniyetin gelişmesindeki rolü, arşivlerin dış politikanın başarısı bakımından değeri, arşivlerin devlet politikalarının devamlılığını sağlamadaki hizmeti, arşivin kurumsal işleyişin hızlandırılmasındaki (zaman kaybının önlenmesindeki) rolü ve arşivlerin kurumlara mali kazanç sağlaması, arşivlerin suiistimallerin önlenmesindeki etkisi konuları üzerinde durmuştur.

\section{a) Arşivlerin idari ve ticari faaliyetlerin yürütülmesindeki rolü}

Arşivlerin birçok faydası vardır. Bu faydaları, -Delmas'ın (1991, s. 10-19) da belirttiği üzeregenel olarak şu şekilde ifade etmek mümkündür: Arşivler; özel hukuk gerçek ve tüzel kişiler ile kamu tüzel kişilerinin taleplerini karşılar ve haklarını korur, ekonomik ve sosyal hayatın düzenlenmesinde rol oynar, üst yönetim kademelerinin harcamalarında tasarruf sağlar, hükümete bilgi sunar, devlet egemenliğinin devamında güçlü bir rol oynar, devlet-toplum-millet birliğini ve bu birliğin devamına imkân sağlar, uluslararası ilişkilerde anlaşmazlıkların giderilmesinde delil sunar. Celal Esad da, eserinde, "Yalnız belediyelerde değil, bütün muâmelât-1 idârîye ve ticârîyede hatta muâmelât-1 husûsîye ve zâtîyede bile kayıd ve hıfz-1 evrâkın ne derece büyük fâide ve hizmetleri olduğunu asr-1 hâzır pekiyi idrâk etmişdir." (Celal Esad, 1331/1915, s. 3) diyerek, günümüz bakış açısına uygun düşen bu türden faydalar üzerinde durmaktadır.

\section{b) Arşivlerin kurumsal hafıza olması}

Arşivler, hakkında bilgi verdiği her şey için bir anlamda hafızadır. Evrakın yazılmasında kullanılan yazının bizzat kendisi, bilgi taşıyıcısı ve açıkladığı konuların (şahıslar, olaylar, yerler, madenler vs.) tamamı hakkındaki bilgi, belgede, dolayısıyla arşivlerde bulunur. $\mathrm{Bu}$ sebeple arşivler, ait olduğu toplum ve konular hakkında bir kültür mirası barındırmanın yanı sıra bulundukları kurumlar/organizasyonlar hakkında da bilgi verir. Kurumlar kendilerini, çevrelerini, örgütsel işleyişlerinin sınırlarını ve -üretilen kayıtlar sayesinde- olaylar/gelişmeler hakkında yeniden düşünme becerilerini arşivler sayesinde kazanırlar (Keskin, 2007/a, s. 21). Bu da, arşivlerin kurumların vazgeçilmez öneme sahip hafızası olduğuna işaret eder. Diğer yandan ait olduğu yapı için bir hafiza olması arşivlerin temel fonksiyonları arasındadır (Delmas, 1991, s. 3). Kurumlar tarafindan üretilen ve arşivlerde korunan belgeler, onların mazisine aittir. Bu nedenle arşivler, kurumsal mazinin ortak, kalıcı ve güvenilir delillerine (belgelerine) sahiptir (Menne-Haritz, 2006). Celal Esad, arşivlere hafıza özelliğini kazandıran önemin sadece arşivlerde bulunan belgelerin korunması ile sağlanamadığı düşüncesindedir. $\mathrm{O}$, bu sürece ayrıca kayıt işlemlerini ve evrakın tasnif edilmesi sürecini de dâhil etmiştir. $\mathrm{Bu}$ 
ifade; arşivi kütlesel bir varlık olarak ortaya çıkartan ve ona topyekûn ortak bir hafıza niteliği kazandıran temel işlemlerin evrakın kayıt ve tasnif işlemleri olduğuna da işaret etmektedir. Esad, bu konuda kuşkusuz haklıdır. Zira evrakın kayıt işlemleri ve tasnif çalışmaları, arşiv sürecini doğrudan etkileyen bir aşamaya işaret eder. Evrakın üretilmesi, daireye kabulü, bürolar arası havale edilmesi, imza-onay işlemleri, kayıt defterlerine evrak hakkında bilgi düşülmesi, düzenleme, koruma ve nihayet arşive intikal süreci, evrakın kayıt işlemleri ve tasnif süreci ile son derece ilişkilidir. Bu da, kayıt muamelesinin arşiv öncesi evrak akış süreci (bürokratik işleyiş) ile birlikte yürütüldüğünü, bu işlemlerin de bir taraftan evrakın güvenilir-delil vasfını garanti ettiğini, düzenlenmesine imkân verdiğini, korumanın ve belgelerden yararlanmanın böylelikle daha fazla ve hızlıca mümkün olduğunu göstermektedir. Celal Esad da, bunun farkındadır. Bu farkındalığını ise şöyle ifade etmiştir: ““'Kayıt ve tasnîf-i evrâk” dâirelerin hâfızasıdır." (Celal Esad, 1331/1915, s. 3).

\section{c) İyi bir kayıt ve evrak koruma yöntemine sahip olmanın faydaları}

Üretilen evrak ve evrak yığını ne kadar fazla ve bunlara sahip kurumlar ne kadar büyük olursa olsun, uygun bir belge yönetimi ve evrak koruma sistemi kullanan işletmeler, belge iş ve işlemlerini tek bir merkezden yönetebilirler. Zira bu sayede evrakın kolaylıkla bulunması ve faaliyetler sırasında kullanılması mümkün olur. Celal Esad, bu durumu şu şekilde ifade etmiştir: "Kayıt ve hıfz-1 evrâk husûsunda muntazam bir usûle mâlik olmayan idâreler inhilâle marûz olduğu gibi kayıt ve deftersiz ticârethâneler de iflâsa mahkûmdur. Muntazam bir usûl-i kayıd ve tasnîf ile bütün dünyânın muâmelâtını bir merkezden idâre etmek kâbildir." (Celal Esad, 1331/1915, s. 3). Ancak böyle bir yararın sağlanabilmesi için yazışmaların denetim altına alınması gerekmektedir. Yazışmaların denetimi ile ulaşılmak istenen beş hedef ise şu şekildedir: 1) Doğru, etkili ve standart bir yazışma formu oluşturmak, 2) belgeyi mümkün olduğunca az maliyetle üretmek, 3) kullanıcıya hızlı ve kaliteli hizmet sunmak, 4) gereksiz yazışma üretimi ve çoğaltımından kaçınmak, 5) yazışmaların kurum içi ve dışında uygun bir şekilde dağıtımını gerçekleştirmek (Odabaş, 2001, s. 163-164).

\section{d) Arşivin kurumsal devamlılık bakımından önemi}

Uygun bir evrak kayıt ve evrak koruma yöntemine sahip olmayan kurumlar doğru, hatası, eksiksiz ve hızlı bir şekilde karar alamazlar ve faaliyetlerini doğru şekilde yerine getiremezler. $\mathrm{Bu}$ sebeple, ilgili kurumun haklarının korunması mümkün olmayacağı gibi muhatap (iş yapılan, ilişki içinde olunan) kurumların ve kişilerin haklarının korunması da mümkün olmaz. Dolayısıyla zaman içinde faaliyetlerin durması ve kurumsal iflas söz konusu olabilir. Celal Esad'ın ifadesi ile iyi bir belge yönetimi ve onların korunması konusunda uygun bir yöntem kullanmayan "[...] idâreler inhilâle marûz olduğu gibi kayıd ve deftersiz ticârethâneler de iflâsa mahkûmdur.[...] Avrupa ticârethâneleri tâ Japonya'dan Newyork'a kadar dünyanın her köşesinde bulunan şûbeleri, komisyoncuları, müşterileri, muhassıllarıyla ancak bu sâyede 
mektublaşır; bu sâyede anlaşır; bu sâyede iş görürler.” (Celal Esad, 1331/1915, s. 3). Günümüz bakış açısına göre de durum bundan farklı değildir. Bu yönde yapılmış bir araştırma; ciddi bir yangın geçiren ve arşivini neredeyse kaybeden kuruluşların \%30'unun bir yıl gibi kısa bir zaman içinde faaliyetlerini durdurmak mecburiyetinde kalacaklarına dikkat çekmektedir (Penn, 1989, s. ix; aktaran: Ataman, 1992). Ekipman ve tesis kayıplarının karşılanması hatta nakit sermayesinin korunmuş olması halinde bile bu durum değişmeyecektir. Bunun nedeni, karar verme aracı olan işletme belgelerinin geri döndürülemeyecek şekilde yok olmasıdır.

\section{e) Medeniyetin gelişmesinde arşivin rolü}

Arşivler geçmişe dair izlere sahiptir. Bu izler; medeniyetin geçmişteki gelişmelerinin izlenmesi için olduğu kadar bugün ve gelecek için de önemlidir. Çünkü tarihsel izler kısa, orta ve uzun vadeli planlamalar bakımından kullanılabilir netlikte delillere/araçlara sahiptir. İnsan ve faaliyetleriyle ilişkili bir varlık olan arşivler, kültür ve medeniyeti oluşturan insanın dünyadaki varlığının, sürekliliğinin, değişime uyumunun (Delmas, 1991, s. 1) ve değişime verdiği tepkilerin delillerine sahiptir. Dolayısıyla arşivler, insanın sahip olduğu hafızanın geçmişe ait delillerine sahiptir. Bu delillerin doğru değerlendirilmesiyle, insanı ve doğasını daha iyi anlamak mümkün olur. Geçmişte üretilen kayıtlar iyi korunmuş olursa, korunan bu kayıtlar -geçmişte olduğu gibi- insan tarafından oluşturulan medeniyetin gelişmesinde kullanılabilir. Celal Esad'ın da ifade ettiği gibi “Denilebilir ki medeniyetin bugünkü derece-i tekâmülü kayıd ve tasnîf sâyesinde vücûda gelmişdir.” (Celal Esad, 1331/1915, s. 3). Dolayısıyla kaydedilmiş ve kullanılabilir şekilde korunmuş olan belgeler, geçmişteki faaliyetlerin hatırlanmasını, hataların ne şekilde yapıldığının ve doğrulara nasıl ulaşıldığının bilinmesini sağlar ve yeni kurumsal fonksiyonların hatasız yürütülmesi daha fazla mümkün olabilir.

\section{f) Kayıt ve evrak koruma yönteminin dış politikanın başarısına etkisi}

Arşivlerin yararlarından biri de, dış politikada oynadığı roldür. Bu rol bir bütün olarak arşivler tarafından sağlandığı gibi aynı zamanda kayıt işlemleri ve evrakın korunması işlemlerinin belli bir yönteme dayanması ile de mümkün olur. Belli bir sistem dâhilinde üretilen, düzenli şekilde korunan ve kolay yararlanılabilir bir sistemin uygulandığ 1 arşivler, sahipleri için vazgeçilmez bir kaynaktır ve aynı zamanda ait olduğu devletin haklarını koruyan bir öneme sahiptir (Keskin, 2008/b, s. 259). Bu bakımdan diplomatik arşivler/dışişleri arşivleri, ülke arşivlerinin tamamlayıcısıdır; bir bölgeye yönelik temel politikaları, bu politikalarda meydana gelen değişimi ve bu değişimin arka planını oluşturan sebepleri ortaya koyar (Kutluoğlu, 1998, s. 230). Arşivler; geçmişte kurulan diplomatik ilişkiler, tek taraflı/karş1lıklı yapılan hatalar, bunun sonucunda oluşan gerginlikler, yapılan anlaşmaların ve yazışmaların detayları, kişilere, olaylara, kurumlara ve ülkelere yönelik durum tespitleri gibi pek çok alanda yararlı delillere sahiptir. Dış politikaların başarılı/başarısız bir şekilde devamlılığının sağlanması da bu sayede mümkün olur. Diplomatik ilişkiler, diplomatlar tarafından bu deliller sayesinde 
kolaylıkla ve sorunsuz bir şekilde yürütülebilir. Örneğin bir ülkeye elçi tayin edilen kişi, o ülkede daha önceden görev yapmış elçilerin birikimlerini yansıtan belgeler için uygulanan "[...] kayıd ve hıfz-1 evrâkdaki usûl-i tasnîf sâyesinde [...]” (Celal Esad, 1331/1915, s. 3), bulunduğu ülke ile sorumlu olduğu ülke arasındaki diplomatik işleri başarılı bir şekilde yerine getirmesi mümkün olur.

\section{g) Arşivlerin dış politikanın devamlılığını sağlamadaki önemi}

Arşivler; dış politikanın sefirler vasıtasıyla başarılı yürütülmesinde olduğu kadar devlet politikalarının devamı bakımından da önemlidir. Her devlet geçmişten gelen ve geleceğin düzenlenmesi ve yönetilmesi bakımından önemli olan, ısrarla ve istikrarlı bir şekilde toplumun/ devletin geleceğini garanti altına almak üzere uygulanan belli politikalara sahiptir. Bu politikalar çok yönlüdür. İç ve dış politika şeklinde temel iki gruba ayrılacağı gibi bilim politikası, teknoloji politikası, eğitim politikası, enerji politikası, askeri politikalar, sosyal politikalar, şehirleşme politikası, göç politikası gibi çok farklı alanları ilgilendirecek şekilde sayıları çoğaltılabilir, konusal ayrıntı düzeyleri derinleştirilebilir. Celal Esad, bu konuyu şöyle açıklamıştır: "Bir memlekete yeni tayîn olunan bir sefîr o memleketde asırlardan beri bulunan sefîrlerin tecrübe ve malûmâtlarından ancak kayıd ve hıfz-1 evrâkdaki usûl-i tasnîf sâyesinde müstefî̀ olur ve her işde malûmât sâhibi bulunur." (Celal Esad, 1331/1915, s. 3). Celal Esad tarafından ifade edilen bu cümle; arşivlerin, kayıt usullerinin ve evrak koruma yöntemlerinin bir taraftan açık bir şekilde dış politikanın başarısında güçlü bir rol oynadığını anlatırken, bir taraftan da -ancak üstü kapalı olarak- dış politikanın devamlılığında rol oynadığı anlamına gelmektedir.

\section{h) Arşivin kurumsal işleyiş̧in hızlandırılmasındaki (zaman kaybının önlenmesindeki) rolü}

Uygun bir yöntemle düzenlenmiş ve erişilebilir şekilde korunan kayıtlar, hiç kuşkusuz işlemlerin yürütülmesinde işlem yapanlara hız kazandırır ve gelecekte bile -konunun her yönü ile doğru bir şekilde- belgelenmesi sağlanır; bu da, başta yeniden yapılması mecburiyetini ortaya çıkartan düzenleme çalışmaları, az personel istihdamı, kurum içi ve kurum dışı doğacak anlaşmazlıkların önlenmesi gibi kurum için pek çok yönden tasarruf ve kazanç anlamına gelir. Celal Esad'ın ifadesi ile “Kayıt ve tasnîfde usûl, zaman ziyâını mâni' olduğu cihetle idârede kuvvet ve zenginlik demek olduğu gibi her ne zaman olursa olsun hatta beş on sene sonra bile bir işin tekmîl teferruâtıyla tedkîkine imkân verir." (Celal Esad, 1331/1915, s. 3). Böylece kurumsal verimliliğe olumlu yönde katkıları olduğu sürece, karar mekanizmaları nazarında arşivlerin güç ve itibarı artacaktır.

\section{1) Bir tasarruf ve kurumsal güç aracı olarak arşivler}

Evraka hızlı, vaktinde ve eksiksiz erişilmesi, kurumlar için, aynı zamanda kazanç anlamına gelir. Evraka hızlı erişim vaktinde, eksiksiz ve doğru karar alabilmeyi, bu da, işlerin hızlı 
yürümesini, daha az personel istihdamını, idari, mali ve hukuki sorunların önüne geçil(ebil) mesini beraberinde getirir. Celel Esad da, buna işaret ederek "Kayıt ve tasnîfde usûl, zaman ziyâını mâni' olduğu cihetle idârede kuvvet ve zenginlik demek [...]" (Celal Esad, 1331/1915, s. 3) olduğunu ifade etmiştir. Dolayısıyla arşivler bugün olduğu gibi o gün de kurumlar için bir güç ve tasarruf aracı olarak görülmüştür.

\section{i) Yararlanılabilir kayıtların personel verimliliği üzerindeki etkisi}

Kayıtların düzenlenmesinin hızlı erişim ve eksiksiz karar almak/işlemleri hızlandırmak gibi doğrudan yararının yanı sıra dolaylı denilebilecek yararı da söz konusudur. Dolaylı yararlar arasında personel moralinin, çalışma heyecanının/hevesinin ve iş disiplininin yüksek tutulması bulunmaktadır. Bu durum; sadece işleme ilişkin evrakın arama süresinin kısaltılması ve kazanç sağlanması için değil aynı zamanda personelin iyi bir psikoloji ile görevlerini yerine getirmeleri bakımından da önemlidir. Celal Esad, bu konuya temas etmeyi ihmal etmemiştir. O’na göre; "İşte kayıt ve hıfz-1 evrâk usûlü [...] memûrların ahvâl-i mâneviyelerini dahi dâimâ uyanık bulundurmak ve teftîşât-1 dâime ile memûrları muntazam çalışmaya ve her günkü işi günü gününe yapmaya alıştırmak için dahi lâzımdır.” (Celal Esad, 1331/1915, s. 3). Günümüzde de örgütler için belge yönetimi ihtiyacı açıklanırken, ortaya konulan somut olmayan ihtiyaçlar arasında personelin iş verimliliğine katkısı önemli bir değerdir.

\section{j) Arşivlerin suiistimallerin önlenmesindeki önemi}

Arşivler, her şeyden önce hukuken kanıt değeri olan kayıtlara sahiptir. Bu kanıtlar; bir taraftan kurumsal denetim için diğer taraftan da işlemleri yürüten personel davranışlarının kontrol altında tutulması, ihmalkârlıkların önlenmesi ve personele/işlemlere dayalı olumsuzlukların engellenmesi bakımından önemli bir işlev görür. Zaten tarih boyunca kurumlar tarafindan üretilen evrakın dikkatli bir şekilde korunmasının nedenlerinden biri de, ihmallerin ve hukuksuzlukların delil niteliği taşıyan kayıtlar yoluyla önlenmesi arzusudur (Keskin, 2007, s. 65-66; Keskin ve Kutluoğlu, 2013/a, s. 478-481; Keskin ve Kutluoğlu, 2013/b, s.187-188; Keskin-Kutluoğlu, 2015, s. 236-239). Bu yüzden, kurumların mali bakımdan denetlenmesi ve kayıtların hukuken denetim süreçlerinde bir araç olarak kullanılması hep söz konusu olmuştur. Celal Esad da buna atıf yapmıştır: "Kayıd ve tasnîfde usûl, [...] her ne zaman olursa olsun hatta beş on sene sonra bile bir işin tekmîl teferruâtıyla tedkîkine imkân vereceğinden her türlü ihmâl ve sû-i istimâlin husûlüne mâni'dir.” (Celal Esad, 1331/1915, s. 3).

\subsubsection{Düzenli Bir Kayıt ve Tasnif Usulünün Uygulanmasındaki Zorluklar}

\section{a) Belge ve arşiv yöneticilerinin bilgi ve becerisinin önemi}

Kayıt ve arşiv iş ve işlemleri mesleki ehliyeti olan kişiler tarafından yerine getirilmelidir. Kayıt ve arşiv işlerinin beklenen düzeyde başarılı yönetilmesi böylelikle mümkün olabilir. 
Alaylı tarzda yani usta-çırak düzeyinde gerçekleşen bir eğitim sonrası arşivcilik mesleğine intisap etmenin uzun bir geçmişi olmakla birlikte, esas mesleki eğitimin 1821 yılında kurulan (Paris ve Münih) arşiv eğitim kurumlarıyla mümkün olduğu ve böylelikle mesleki faaliyetlere dâhil olunduğu bilinmektedir (Keskin, 2008, s. 7-8). İster usta-çırak tarzında olsun ister bir eğitim kurumu vasıtasıyla alınan eğitim sonrası mesleki intisap gerçekleşsin önemli olan, mesleki icra kabiliyeti ve vasıfları olan bir meslek mensubunun mesleki görevleri icra etmesi ve yeterlilik göstermesidir. Yine meslek mensubunun ruh dünyasının da bu yolda belirgin bir rolü vardır. Celal Esad'a göre; "Kayıd ve tasnîfde onu tatbîk edecek memûrînin zihniyet ve kâbiliyet-i dimâiyeleri nazar-1 itibâra [...]"' (Celal Esad, 1331/1915, s. 4) alınması gerekmektedir. Dolayısıyla tayin olacak memurun mesleki eğitimden kaynaklı becerilerinin yanı sıra, onun zihniyeti ve zihinsel kabiliyeti de dikkate alınmalıdır.

\section{b) Geleneksel ve alaylı bilgi ile klasik eserlerin yetersizliği}

Celal Esad'ın belirttiğine göre; büro içinde memurlar arasında elden ele dolaşan ve bilimsel bir öneme sahip olmayan Gülistân-ı Fârisi ve Kısâs-ı Enbiyâ gibi el kitapları söz konusudur. $\mathrm{Bu}$ eserler memurlara artık bir fayda sağlamamaktadır ve büro işlerinin yürütülmesinde de bir yararları söz konusu değildir. Bu gibi eserlerin işe yarayacağı düşünülen devirler çoktan geçmiş, geride kalmıştır. Büroların bu gibi eserlerle ve geleneksel tecrübeden beslenen kurum kültürü ile yönetilebilmesinin imkânı kalmamıştır. $O$, bu yöndeki düşüncesini şu şekilde açıklamıştır: “[...] oda oda dolaşan Gülistân-1 Fârisi veya Kısâs-1 Enbiyâ'nın kapağı içerisine kayıd edilmiş birkaç tarih veya adresle iş görülecek zamanlardan uzak bulunduğumuz ve bugün bütün medenî insanlarla beraber gitmek mecbûriyetinde olduğumuz cihetle tekâmülde sürat aramamız lâzımdır.” (Celal Esad, 1331/1915, s. 4).

\section{c) Kayıt ve evrakın korunması usullerinin gerekliliği ve basitliği meselesi}

Kurumlar evrakın üretilmesi, düzenlenmesi, -birim, kurum ve devlet arşivlerine naklikorunması konularında yöntemlere ihtiyaç duyar. Bu ihtiyaç daha çok zorunluluk türünden bir durum ortaya çıkartır. Celal Esad'a göre; Osmanlı kamu kurumlarının genelinde evrak üretimi, korunması ve düzenlenmesi için uygulanan bir usulün var olup olmadığı cevabı zor olan bir konudur. Bir usulün varlığı ile yokluğu hususunda neredeyse eşitlik söz konusudur. Buradan anlaşılması gereken, kurumlarda kayıt ve evrakın korunması ile ilgili bir anlayışın varlığıdır. Kayıt ve evrakın korunması konusunda bir bilince işaret eden bu anlayış, kurumların ancak yarısında görülebilir bir durum arz etmemektedir. Celal Esad'ın ifadesi ile "Bugün dâire-i resmîyelerimizin ekserîsinde mevcûd olan usûlün varlığıyla yokluğu hemen müsâvî gibidir." (Celal Esad, 1331/1915, s. 4). Bu da, kurumların neredeyse yarısında herhangi bir sistemin uygulanmadığını ve diğer yarısında ise -başarısı hakkında emin olamadığımız- bir yöntemden "muhtemelen" söz edilebileceğini göstermektedir. Bu konuda zaman zaman ıslah çalışmaları da yapılmaktadır. Avrupa'da denenmiş bir usulün Osmanlı kurumlarına uygulanması söz konusu 
olduğunda, bu iş için kurulan komisyon tarafından hemen birtakım itirazlar yükselmektedir. Bu itirazın temel sebebi ise karmaşık usullerin uygulanmasında Osmanlı memurlarının güçlük çekeceği ve nihayet çalışmanın başarısız olacağı yönündedir. "Kayıd ve hıfz-1 evrâkın ne zaman ıslâhı mevzû-1 bahs olsa Avrupa memâlik-i mütemeddinesinde tatbîk olunan usûllerden biri teklîf olununca, bu husûsda teşekkül eden komisyonun ilk sözü 'biz böyle komplike usûlleri tatbîk edemeyiz" kanâati olmuşdur.” (Celal Esad, 1331/1915, s. 4). İşin basitleştirileceği yerde daha da zorlaştırılması söz konusu olmaktadır. Belli ki, büro yönetimi usullerinin geliştirilmesi çabaları olmuş, bu çabalar memurları birtakım güçlüklerle yüzleştirmiş, belgelerin/evrakın adedi gereksiz yere artmış ve üstelik işler de belli bir kurala bağlanamamıştır. "Basît yapalım diye defterlerin adedini çoğaltırız, muâmelâtın sûret-i cereyânını tafsîlâtıyla düşünerek bir kâide-i muttarideye rabt edemeyiz. Bir defter, bir defter daha, derken öyle bir hale geliriz ki ne kayıd ne kuyûd bulmak kâbil olamaz." (Celal Esad, 1331/1915, s. 4). Kayıt için üretilen defterlerin adedinin çoğaltılması, bu nedenle üretilen kayıtların bulunmasında güçlük çekilmesi, uygulamanın belli bir kurala bağlanamaması ve evrakın bulunması için yardımcı araçların üretilmesinin fayda sağlamaması söz konusudur. "Evrâkı taharrî için muâvene defterlerine lüzûm görülür, defterlerin adedi artdıkca artar velhâsıl korkduğumuz usûlden daha güç bir usûle düşeriz. [...] Devâir depoları yalnız birkaç sahîfesi işgâl edilmiş binlerce çeşit kayıd ve tasnîf defterleriyle doludur." (Celal Esad, 1331/1915, s. 4). Yine kayıt ve arşiv yönetimi usulleri belli bir yönteme dayanmakla birlikte basit de olmalıdır. Seçilecek usul, her zaman elde mevcut kayda daha hızlı ve kolay erişimi sağlayacak türden özellikler içermelidir. Bu yüzden, "Kayıd ve tasnîfde [...] basit usuller ittihâzı [...] (Celal Esad, 1331/1915, s. 4) gereklidir.

\section{d) Usullerin uygulanmasında süreklilik ve uygun memurlarla çalışılması}

Hangi iş olursa olsun, uygulamaya konulan usullerin -önemli bir sorun gündeme gelmedikçeterki hatalı bir davranıştır. Bu da, işlemlerde devamlılığın ve sabrın önemine işaret eder. Osmanlı idari kademelerinde ihdas edilen uygulamaların çok geçmeden terkinin söz konusu olduğu, bu duruma da genellikle atanan idarecinin neden olduğu Celal Esad'ın ifadelerinden dolaylı olarak anlaşılmaktadır. Uygulamanın yürürlüğe girmesinden kısa zaman sonra yöneticinin değişmesi ve onun yerine yeni yöneticinin atanması, zaten yönetici atamasından kısa zaman sonra uygulamaya konulan usulün terkini gündeme getirmekte ve yeni yönetici ile birlikte yeni 1slahat çalışması söz konusu olmaktadır. Yaşanan bu olumsuz tecrübeler, büro ve evrak işleri konusunda geliştirilen usullerin ve çalışmaların bir sonuca kavuşmasının önündeki en büyük engel gibidir. Bu işlerde bir diğer engel ise işe göre memur değil memura ve memur adedine göre iş ihdas edilmesidir. Yeteri kadar ve nitelikli memur ile işe başlanması ve uygulamalarda devamlılık sağlanması başarının anahtarıdır. Celal Esad'a göre;

[...] Memûrların zihniyet ve adedine göre usûl aramakla hiçbir netîceye vâsıl olmak kâbil değildir. Memâlik-i sâirede tatbîk olunmuş ve iyi netîceler vermiş usûllerden en basit olanı alınır ve o usûlün tatbîkine lâzım olan mikdarda memur tayiniyle 
teşkilât-1 lâzıme yapılır ve işe başlanırsa daha kat'î netîceler elde etmek kâbil olur. (Celal Esad, 1331/1915, s. 4).

\section{e) Usullerin uygulanmasında devamlılığın memur tecrübesine etkisi}

Bürolarda ve kayıt usullerinin niteliğinin yükseltilmesi için hayata geçirilen usullerde sıkça yapılan -sözde- 1slahat çalışmaları, yetkililerin değişmesi hatta nitelikli ve yeter sayıda memur istihdamının gerçekleştiril(e)memesi gibi nedenler memurların uygulamada yetkinlik kazanmasına mani olmaktadır. Önemli olan; memurların zihniyet ve adedine göre çözüm aramak değil, tam aksine başka ülkelerde başarısı ispat edilmiş ve en basit olan usulü almak, yeter sayıda memur istihdam etmek ve organizasyonu uygun şekilde düzenlemektir. $\mathrm{Bu}$ konularda hassasiyet söz konusu olmayınca da, "Usûl böyle her sene değişmesi hasebiyle o usûlde meleke kazanan memur da yetişmez.” (Celal Esad, 1331/1915, s. 4). Celal Esad, bu yüzden ve haklı olarak kabiliyetli memurların yetişmesi için hayata geçirilen büro ve yönetim uygulamalarının devamlılığını şart koşmaktadır.

\section{f) Kayıt ve evrak usullerinin olgunlaşması için zamana ihtiyaç olduğu}

Kayıt işlemleri ve evrak yönetimi usullerinin uygulanmasının başlangıcında bazı hatalar olabilir. Durum öyle olsa bile, zamanla yazışma ve düzenleme usullerinde düzen hâkim olur, düzen sağlanır ve memurlar işinde meleke-tecrübe kazanır. Celal Esad, bu hususa şöyle temas etmektedir: "Bi't-tabîi ilk senelerde bazı hatalar husûle gelecekdir fakat yavaş yavaş tashîh edilir ve ancak bu sûretle mütehassıs memûrîn yetişerek kayıd ve tasnîf muâmelâtı da mümkün olduğu kadar süratle bir şekl-i muttarid ve muntazam almış olur.” (Celal Esad, 1331/1915, s. 4). Bununla birlikte kayıtların üretilmesi ve düzenlenmesi hakkındaki usulde idarenin durumuna bağlı farklılıklar (Celal Esad, 1331/1915, s. 5) da söz konusu olabilir.

\section{g) Mesleki el kitaplarının gerekliliği}

Diğer yandan usullerin öğrenilmesi ve uygulanmasında eğitici-öğretici el kitaplarının rolü büyüktür. Diğer medeniyetlerde olduğu gibi, İslam coğrafyası devlet yönetimi kültüründe bu el kitaplarının ayrı bir yeri vardır. Kitabet-i resmiye adı verilen resmi yazışmaların yürütüldüğü kitabet (yazı) işlerinin kolaylıkla yürütülmesi ve kâtiplerin hem mesleklerini öğrenmeleri hem de uygulama sırasında karşılaştıkları sorunları çözmeleri için hazırlanan risaleler İslam coğrafyasında, doğal olarak Osmanlı idare kültüründe oldukça yaygın idi (İpşirli, 1995). Gerek eğitim sırasında gerekse mesleki uygulamaya dâhil olunduktan sonra, bu türden eserler, yetişme durumundaki ve yetişmiş olan meslek mensuplarının doğru mesleki bilgileri öğrenmeleri için vazgeçilmez kaynaklardır. Celal Esad'ın belirttiği üzere; “[... od oda oda dolaşan Gülistân-1 Fârisi veya Kısâs-1 Enbiyâ'nın kapağı içerisine kayıt edilmiş birkaç tarih veya adresle iş [...]” (Celal Esad, 1331/1915, s. 4) görülmesi mümkün değildir. Buradan anlaşılması gereken ise kayıt ve evrak usullerini anlatan eğitici-öğretici (el) kitapların(ın) hazırlanması ve memurlara dağıtılmasıdır. 


\subsubsection{Kâğıtların Ebat ve Şeklinde Birlik}

\section{a) Evrakın standart olmasının büro ve evrak yönetimi bakımından önemi}

Kayıt işlerinde kullanılan kâğıt boyutlarının standart olması özellikle aranan bir evrakın bulunması, evrakın korunması, dosyalama işlemleri ve evrak işlemlerinde düzenin sağlanması bakımlarından önem arz etmektedir. "Bu cihet gerek esnâ-yı tedkîk ve muâmelede ve gerekse tasnîfde büyük kolaylığı mûcib olur ve intizâmı temîn eder.” (Celal Esad, 1331/1915, s. 5). Bu durumu dikkate alan günümüz uygulamaları bürolarda kullanılmakta olan kâğıt konusunda birtakım standartlar geliştirmiştir. Yazışma usulleri konusunda çıkartılan mevzuat da kısmen bu hususu düzenlemektedir (Resmî yazışmalarda uygulanacak..., 2020). Celal Esad, "Binâenaleyh muâmelât-1 resmîyede kullanılan kâğıdlar tasnîf cüzlerinden hârice taşmamak üzere 21x31" (Celal Esad, 1331/1915, s. 5) ebatlarını geçmemesi gerektiği şeklindeki bir usulün uygulandığını belirtmektedir. Günümüzde ise bu yöndeki uygulamaların genellikle A4 (210x297 mm) standardı doğrultusunda gerçekleştirilmesi; belge eklerinin ise farklı form, format ve ebatlarda olabileceği (Resmî yazışmalarda uygulanacak..., 2020, m.6/1) bilinmektedir. Bu konuda önemli olan diğer bir husus da belge türlerine bağlı bazı usullerin uygulanmasıdır. Modern diplomatik usulleri de bu konuya yönelik çözümler üretmiştir (Kütükoğlu, 2018; Çiçek, 2003; s. 237-287; Özdemirci ve Odabaş, 2005, s. 80-94 . Bunlardan ikisi evrak üzerinde antet/başlık ve adres gibi kısımların matbu olması uygulamasıdır. Bu türden uygulamaların nedeni ise her zaman tekrar edilen bazı ibarelerin tekrar tekrar yazılmasına mani olmak, işlemlerde zaman kazandırmak ve tasarruf sağlamaktır. "Raporlar, müzekkireler, mazbatalar, ruhsâtiyeler, encümen kararları vesâireye mahsûs olan kâğıdlar üzerinde de her zaman tekrârı lâzım gelen ibâreler kolaylık olmak üzere matbu' bulunmalıdır.” (Celal Esad, 1331/1915, s. 5).

\section{b) Kâğıt üzerindeki işlem usulleri ve kâğıdın kullanım şekli}

Osmanlı kamu dairelerinin hemen tamamında, resmi muameleler için -kâğıdın pahalı olduğu zamanlardan kalma bir alışkanlıkla- işlemler tek kâğıt üzerine kaydedilmekte ve işlemin uzamasına bağlı olarak yeni bir kâğıdın kullanılması ve bunun da ilk kâğıda yapıştırılması/ bağlanması söz konusudur ve büroya ait günlük işlem (kâğıt) grubunun bir araya getirilerek dürülmesiyle de tomarlar oluşturulmaktadır (Karakaş, Rukancı ve Anameriç, 2009, s. 43). Celal Esad tarafından halen uygulandığı belirtilen bu usulün Tanzimat sonrası yeni idari teşkilatın ve buna bağlı büro uygulamalarının değişmesiyle birlikte uzun zaman önce değişmiş olması, bunun bir sonucu olarak her işlemin ayrı bir kâğıda kaydedilmesi ve işleme ilişkin bütün evrakın bir araya getirilmesi ile birlikte de dosyaların oluşturulması gerekirdi (Keskin, 2007/b, s. 294). Ancak uygulamanın -boyutunun tam olarak değerlendiremediğimiz bir şekilde- değişmediği Celal Esad tarafından belirtilen durumdan bariz şekilde anlaşılmaktadır. Halen uygulanmakta olan durum şu şekilde anlatılmaktadır: "Devâirimizin hemen kâffesinde bugün muâmelât-1 resmîye, kâğıd pahalı olduğu zamanlardan kalma bir itiyâd ile tek kâğıd üstüne yazılmakda 
ve muâmele uzayınca altına başka kâğıdlar yapışdırılarak kurûn-1 vustâdaki tomarlar hâline sokulmakdadır." (Celal Esad, 1331/1915, s. 5). Ancak bu uygulamanın sakıncaları tecrübe edilmiştir. Evrakın yapıştırıldığı/birleştirildiği yerden hatta derkenarların kesilip araya başka eklemelerin yapılması resmi işlemlerde izin verilemeyecek bir durumdur. "Evrâk-1 resmîyeye istenildiği yerden kâğıd yapışdırılarak ilâvesi derkenârların kesilib başka ilâvelerle tebdîli umûr-1 resmiyede tecvîz olunamayacak husûsâtdandır." (Celal Esad, 1331/1915, s. 5). Bu uygulamanın yerine, -Avrupa ülkelerinde olduğu gibi- çift yapraklı kâğıt uygulamasının hayata geçirilmesi gerekmektedir. 'Bunlara kâğıd ilâvesi lâzım geldiğinde sahîfe numaraları vaz' olunmak ve yekdiğerine kitâb sahîfeleri gibi ilsâk edilmek sûretiyle gerek tedkîki ve gerekse muhâfazası kolay bir şekil verilmiş olur." (Celal Esad, 1331/1915, s. 5). Bu durum, bir israf olarak da addedilmemelidir. "Vâkıâ bazen bir satırlık yazı için iki sahîfe kâğıdı sarf etmeği isrâf addedenler de bulunursa da bu hiç bir zamân isrâf değildir.” (Celal Esad, 1331/1915, s. 5). Bir muamelenin ne kadar işlem gerektireceğinin belirsizliği, evrak işlerinde düzen sağlanması ve yöntemin uygulanması adına bu durum göze alınabilir. Milyonlara varan derecede kayıt üreten bir kurum için bu durumun göze alınması daha da mümkündür (Celal Esad, 1331/1915, s. 6).

Diğer yandan, işlemlerde kullanılan kâğıdın cinsi ve sağlamlığg üzerinde özen göstermek gerekmektedir. "Kullanılan kâğıdların cinsi de mürûr-1 zamanla yırtılmayacak bir metânetde olması lâzımdır." (Celal Esad, 1331/1915, s. 6). Evrakın iki sütün halinde tertibi gerekir. İşlem dolayısıyla tüm satırın doldurulmadığı genel durum karşısında iki sütunlu kâğıtlar tasarruf sağlamaktadır.

Kâğ1dlar umûmiyetle ya şâkûlî bir çizgi veyâhûd ortadan kırılarak iki sütuna ayrılmalıdır. Bu sûretle kısa muâmelâtdan husûle gelen satırlar tekmîl sahîfeyi işgâl etmeyeceği cihetle yer kazanılmış ve mütâlaası teshîl edilmiş ve bazen birkaç kelîmeden ibâret havâleler, tasdîkler ve mühürler için uzun birkaç satırlık mahal işgâl edilmemiş olur. (Celal Esad, 1331/1915, s. 6).

\section{c) Evrakın unsurlarına dair}

İster bir mektup isterse resmi ve özel bir yazışma nedeniyle üretilsin her belge, belli form özelliklerine sahip olarak üretilir. Bir belgenin sahip olduğu bu özellikler, onun özel, resmi ve ne tür bir fonksiyon ve faaliyet için düzenlendiği ile yakından alakalıdır. Bu form özellikleri, genel bir teamülün ürünüdür ve benzerleri -aynı amaç için üretilenler- ile -neredeyse- aynı görünüme sahiptir. Diğer yandan bu benzerlik yazı alanının düzenlenmesi ve metnin yazılma şeklinde de kendisini gösterir. Bu uygulamaların ilk örneklerini eski medeniyetlerin evrak üretme uygulamalarında da görmek mümkündür. Pers, Bizans ve onlardan sonraki yönetim uygulamaları özellikle resmi evrakın düzenlenmesinde bazı kuralların uygulanmasının zorunlu olduğunu göstermektedir (Bloom, 2003, s. 265-268; Keskin ve Kutluoğlu, 2015, s. 240-242). Evrak üzerinde konu, ilgi, tarih, başlık gibi bazı unsurların bulunması doğal olarak gereklidir. Bu durum, hem düzenleme hem de evrakın kurum 
içinde hangi birime ait olduğu, işlem türünün belirlenmesi ve standart özellikler taşıması, işlem tarihi ve düzenleme bakımlarından önemli bir işlev görür. Bütün bunlar, modern evrak işletmeciliğinde uygulanan usullerdir (Çiçek, 2018, s. 42). Celal Esad, ait olduğu daire ve büro ismi, (genel ve özel) kayıt numaraları ve tarihin evrak üzerinde olmasını gerekli unsurlar olarak değerlendirmiştir. Bunu da şu şekilde ifade etmiştir: "Her kâğıd üzerinde âid olduğu dâirenin ve şûbenin ismi, umûmî ve husûsî numaraları ve târihi bulunmalıdır.” (Celal Esad, 1331/1915, s. 6).

\section{ç) Muamelatın iki kısma ayrılması hususu}

Celal Esad tarafından "Kitâbet-i umûmîye" şeklinde ifade edilen evrak işlemlerinin (muamelatın) iki temel yönü vardır: İşlemin kayıt altına alınması (kayd-ı evrâk) ve evrakın korunması (hıfz-1 evrâk). İşlemin kayıt altına alınması, genellikle daireye gelen ve daireden çıkan evrakın kayıt işlemleri şeklinde ifade edilen "genel kayıt/kayd-ı umûmî", diğeri de büroların kendine ait olmak üzere tuttuğu kayıtlar, yani "kayd-1 husûsî” süreçlerinden ibarettir. Kitâbet-i umûmî de aynı şekilde kendi içinde ikiye ayrılır: İşlemi tamamlanmamış evrakın bürolardaki dosyalama işlemleri ve muamelesi son bulan evrakın korunduğu evrak mahzeni, yani arşiv (Celal Esad, 1331/1915, s. 6).

\section{d) Büro-arşiv deposunun mekânsal yakınlığı}

Genel kayıt ve arşiv deposu alanlarının mekânsal yakınlıkları işlemlere hız kazandırmak nedeniyle önemlidir. Geçmiş dönemlerin günümüz teknik imkânlarından yoksun oluşu bu konuda özellikle hassasiyet oluşturmaktadır. Mekânlar fiziki olarak birbirinden uzak olursa, evrakın ulaştırılması için yeterli personel istihdamı ve ilgili personelin de zamana ve iş ahlakına sahip olması gerekir. Yine yazı işleri bürosunun düzeninin ve depolama maksatlı kullanılan dolapların muamelatı kolaylaştıracak vaziyette bulunması gerekmektedir. Celal Esad, bu duruma şu şekilde vurgu yapmıştır: "Kayd-1 umûmî ve mahzen-i evrâk muâmelâtının yekdiğerine olan râbıtaları hasebiyle devâirde bunlara tahsîs edilecek odaların mümkün mertebe yan yana olması ve gerek yazıhâne ve gerek dolabların muâmelâtı teshîl edecek şekil ve vaziyette bulunmasına dikkat olunması lâzımdır." (Celal Esad, 1331/1915, s. 6-7). Yazar, buna ilave olarak bir de genel kayıt ve evrak mahzeni işlerinde çalışacak yönetici ve memurlar için yerleşim krokisi düzenlemiştir. Bu krokiye göre genel kayıt bürosu personeli ile evrak ve defterlerin konulacakları alanın birbirine yakınlıkları ve kolay erişilebilirliği dikkat çekmektedir (Celal Esad, 1331/1915, s. 7).

\subsection{Genel Kayıt Bürosu İşlemleri}

\section{a) Genel kayıt bürosunda kayıt işlemleri}

Celal Esad, eserinde, günümüzde kısmen “evrak işletmeciliği” şeklinde ifade edebileceğimiz faaliyet alanı hakkında, diğer konulara oranla biraz fazla durmuştur. O, genel kayıt bürosuna 
ve sorumluluklarına verdiği önemi şu şekilde açıklamaktadır: "Kayd-ı umûmî dâirenin kapısı demekdir. Hiçbir evrâk kayd-1 umûmîden geçmeksizin dâireye giremez." (Celal Esad, 1331/1915, s. 8). Esad'ın bu hassasiyetinde haklı olduğu düşünülebilir. Zira evrak işletmeciliği konusunda özel bir yatırım yapmamış organizasyonların işletme faaliyetlerinde başarılı olması imkân dâhilinde değildir. İşletmelerde-kurumlarda karar vericilerin hızlı karar almaları ve alınan kararın doğruluğu-eksiksizliği, faaliyete ilişkin -ve daha çok iç kaynaklı olan- bilgi kaynaklarından süratli bir şekilde sağlanmasını gerektirir. Faaliyete ilişkin ihtiyaç duyulan bilgi kaynaklarının elde edilmesi ise evrak ve arşiv hizmetlerinin düzenli olmasına bağlıdır. Bu da, evrak ve arşiv hizmetlerinin düzeni ile alakalı ve önceden eksiksiz bir şekilde hayata geçirilmiş kuralların varlığına ve gerekliliğine işaret eder. Evrak ve arşiv süreçlerinin ve hizmetlerinin düzeninde rol oynayan bütün faktör ve konuların değerlendirilmesi bu yüzden önemlidir.

Belge yönetimi, faaliyetlerin yürütülmesi için ihtiyaç duyulan kayıtlar üzerinde sistematik ve bilimsel kontrol uygulanması şeklinde açıklanır (Ataman, 1992). Bu kontrol, örgütlenmenin ihtiyaç duyduğu her türden evrakın üretilmesi, dağıtılması, kullanımı, saklanması, depolanması, yeniden erişimi, korunması ve tasfiyesi işlemlerini ihtiva eder. Belge yönetiminin başlıca fonksiyonları olan bu iş ve işlemler, belgelerin yaşam döngüsündeki bütün safhaları kapsamaktadır. Bu yüzden, evrak işlemleri için belirtilen kurallar/standartlar her aşamada uygulanmalı, politika ve prosedürler formüle edilmelidir. Kuralların uygulanmasının yanı sıra politika ve prosedürlerin hayata geçirilmesi sayesinde, faaliyet için ihtiyaç duyulan bilgi gerektiği anda, doğru ve bütünlüklü olarak elde edilebilir, işlenebilir, nitelikli hizmet verilebilir. Üstelik bu hizmetler mümkün olan en düşük maliyetle sunulabilir.

Celal Esad, genel yazı işleri bürosunun işlemlerini şöyle sıralamaktadır: Faaliyetlerin yazılı evrak ile başlaması, evraka kayıt numarasının verilmesi, evrakın işlem görecek büroya/bürolara havalesi, havale işleminin kayıtlı ve imza karşılığında gerçekleştirilmesi, havale pusulalarının matbu ve renkli olması, kayıt memurunun işini kolay yapması için oturduğu masanın gözlerinin evrak havale edilecek büro sayısınca olması, evrakın özetinin çıkartılması, evrakın tasnifi ve araştırma (taharri) defterine kaydedilmesi, esas kayıt defterinin düzenlenmesi, evrakın işlem gördügü bütün bürolara dair kayıt işlemlerinin yapılması, mahrem ve gizli evrakın özel kalem tarafından işleme alınması, evrak üzerinde tashih ve tahrif olmaması eğer olursa metindeki tashih noktasının çizilmesi ve yetkilinin onayının olması. Yapılması istenen bütün bu işler yerine getirilirken dikkat edilmesi gereken hususlar hakkında ayrıca şu tavsiyeler söz konusudur: Memurlar zeki ve idrak kabiliyeti yüksek olmalı, maaş imkânı iyi olmalı, kayıtsız hiçbir işlem yapılmamalı, yetkiler iyi paylaşılmalı, işler yetki ve sorumluluk temelinde halledilmeli, elden iş görülmemeli (Celal Esad, 1331/1915, s. 7-15). O’na göre, muhtemel hatalar da şu şekilde gerçekleşir:

"Kayıd memûrlarını yalnız numero koymağa mahsûs bir tamgacı gibi ad ile oraya üç-dört yüz kuruşluk bir memûr koymak gâyet yanlışdır. Muâmelâtı çok olan devâirde nâzır ve müdîrlerin vakitlerinin kısm-1 'azamı kâğıd okumak ve havâle 
etmekle geçer. Buna sebeb olan şey de re's-i kârda bulunanların her şeye vâkıf olmak ve bütün muâmelâta hâkim olmak istemeleridir. İdârede bu zihniyet gâyet muzırdır. İdârenin ruhu "salâhiyet ve mesûliyet" esâslarına müstenid olmalıdır." (Celal Esad, 1331/1915, s. 8-9).

İdarecilerin her şeye vakıf olma arzuları işlerin yavaşlamasına sebep olmaktadır. Bu yüzden, memurlara güvenilmesi, işlerin paylaşılması ve işlerin sorumluluk sahibi kişilere terk edilmesi gerekmektedir. Böylelikle memur sayısının azaltılması ve işlemlerin hızlı görülmesi söz konusu olacağından, kurumsal bakımdan tasarruf elde edilmiş olur. Bu düşüncelerini Celal Esad şu şekilde belirtmektedir:

[...] şehremininin "bâ-husûs İstanbul gibi daha henüz belediyesi teessüs etmemiş bir şehirde" o kadar çok işi ve o kadar az vakti vardır ki bu gibi teferruât-1 umûru şâyân-1 itimâd ve mesul ellere bırakmadıkça yetişebilmesi imkân hâricindedir. Hatta evrâkın kayıd memûru tarafından alınıb evrâk müdîrine verilerek havâle etdirilmesi bile fazla bir işdir. Kayıd memûru muktedîr olursa o kâğıd aynı zamanda hem kayıd hem de havâle olunarak hem memûrun adedi idâre edilmiş hem de vakit kazanılmış olur. Aşağıda görüleceği vechile evrâk müdîrinin kendine âid işlere ancak vakti yetişir. Evrâkın havâlesinde büyük bir ehemmiyet-i idârîye görmek yanlışdır. Bu eski zamânların yâdigârıdır. Bir kâğıd yanlış olarak havâle olunsa bile yine şûbesi onu diğer şûbeye gönderir. Her işe âgâh olub onu hâfızada tutmak veya küçük bir deftere kayıd etmekle takîbâtda bulunmak hiçbir âmirin kârı değildir. (Celal Esad, 1331/1915, s. 9).

Yine kayıt defterleri basit düzenlenmeli ve işlemler kolaylaştırılmalıdır. "Kayıd defterlerinde ne kadar az hâne olursa istîmâli o kadar sâde ve kolay olacağı gibi edilecek istifâde de o nisbetde çok olacağı bi’t-tecrübe anlaşılmışdır (Celal Esad, 1331/1915, s. 11). Celal Esad'ın bu konuda üzerinde durduğu önemli konulardan biri de, şehremanetinden kurum içi gerçekleştirilen yazışmaların -ve bir alt daireye gönderilen evrakın- genel kayıt işlemlerinin yapılmasıdır.

Şehremâneti bir dâire itibariyle devâiri aynı dâire gibi addederek onlara şehremânetinden gönderilen evrâkı kayd-1 umûmîden geçirmemek câiz olamaz. Böyle bir tefekkür muâmelât-1 kuyûdiyeyi; içinden çıkılmaz bir hale kor. Dâireler salâhiyet-i idâreye mâlik bir şube-i müstakile olduklarından onlarla Emânet [şehrelaneti] arasındaki muâmelât, kuyûdâtda tıbkı haric-i emânet muâmelâtı gibi telakkî edilmelidir. (Celal Esad, 1331/1915, s. 14-15).

\section{b) Gizli yazıların görülebilirlik izni ve işlemleri}

Gizli yazılar (kontrollü yazılar), bir yazışma türüdür. Ancak bu yazılar sadece yetki sahipleri (makam ve şahıs) tarafından görülebilir (Çiçek, 2018, s. 79-81). Bu yazılar; gizli, çok gizli, 
özel, hizmete özel, kişiye özel biçiminde türlere ayrılmaktadır ve bu belgeler hizmet özelliğine göre kurum veya kuruluş tarafindan belirlenir (Resmi yazışmalarda uygulanacak..., 2020, m. 23). Celal Esad, bu hususa dikkat çekerek;

Mahrem ve husûsî olan evrâk kayd-1 umûmiye uğramaksızın doğrudan doğruya kalem-i mahsûsa verilir. Oranın defterine kayıd olunarak husûsî sıra numarası alır. İşi az olan devâirde muktedir kayıd memurları kullanmak kâbil olamazsa o zaman havâleler başkâtib tarafından yapılabilir. (Celal Esad, 1331/1915, s. 9-10)

demektedir.

\section{3. Şubelerde Kayıt İşlemleri}

\section{a) Dairelerde (şube) ve bürolarda (kısım) gerçekleştirilen kayıt işlemleri}

Bürolarda yapılan kayıt işlemleri genel kayıt bürosu işlemlerinden farksızdır. Burada da genel kayıt bürosundakine benzer bir kayıt defteri tutulur. Ancak genel kayıt bürosu tarafindan kayıt altına alınmamış hiçbir evrak, işlem göreceği büro tarafından kabul edilmez. Bürolara gelen evrak, -genel kayıt bürosunda olduğu gibi- bir numara verilerek kayıt altına alınır, aynı zamanda başka şubede işlem görmesi gereken evrak -genel kayıt bürosu gönderilmeksizindoğrudan ilgili büroya havale edilir, bu havale işlemi ancak büro amirinin havalesi ve onayı ile gerçekleşir, işlemi tamamlanmamış işlerin listesi hazırlanır, evrak faaliyete bağlı olarak dosyalanır ve düzenlenir, işlemi tamamlanan evrak bütün ekleri ve müsveddeleriyle birlikte arşive gönderilir, şubeler (daireler) ve kısımlar (bürolar) arasında alınıp verilen, genel kayıttan geçmeyen işler, raporlar, müzekkireler ve tamimler kronolojik olarak tasnif edilir, sürekli başvurulan emir, nizamname ve tamim gibi evrak arşivde değil -günümüzde olduğu gibibürolarda saklanır, şubeler teslim defteri tutar, evrak mahzenine teslim edilen evrak için de defter tutulur (Celal Esad, 1331/1915, s. 15-18).

\section{b) Bürolarda evrakın düzenlenmesi ve dosyalama çalıșmaları}

Günümüz kurumlarında evrakın düzenlenmesi konusu, üretilirken başlar. Belge yönetimi uygulamaları gereği oluşturulan dosya planları doğrultusunda, bir belge henüz üretilmeden hangi dosyanın bir parçası olacağı belirlenir. Bunun nedeni, belge üretilirken ait olduğu fonksiyon ve konusuna göre dosya planından tasnif kodunun verilmesidir. Celal Esad, önceden hazırlanmış bir dosya planı üzerinde durmaz, aksine evrakın işleminin tamamlanmasının ardından bir dosyalama, düzenleme çalışmasından söz eder. Bununla birlikte Kadıköy Şubesi/Dairesi için hazırlanan bir şablon, hazırlanmış bir dosya planı gibi de değerlendirilebilir (Celal Esad, 1331/1915, s. 20-23). İşlemi tamamlanan evrak, şube kayıt memurları tarafından önce konusuna/türüne göre ayrılmasından, ardından da tarih (kronolojik) sıraya göre düzenlenmesinden söz etmektedir. Evrakın arşive teslimi de bu düzen içinde gerçekleştirilir. Ancak şubelerin sürekli başvurma 
ihtiyacı hissedeceği emir, nizamname, tamim gibi mevzuat ile ilgili kayıtların ilgili şubesinde erişime hazır şekilde sürekli muhafaza edilmesi gerektiği anlatılır (Celal Esad, 1331/1915, s. 18). Celal Esad, bu konuda şu bilgileri vermektedir: Evrak "“[...] şûbelerin mukayyidleri tarafından târîh sırasıyla ayrı ayrı dosyalara tasnîf olunub, bunlar da sene nihâyetinde takımıyla mahzen-i evrâka teslîm olunur." (Celal Esad, 1331/1915, s. 18).

\section{c) Arşive devri gerekmeyen evrak}

Celal Esad, günümüzde olduğu gibi, evrakın bir kısmının arşive teslim edilmeyeceğini belirtir. Bunun nedeni, şubelerin ve büroların evraka başvuru ihtiyacıdır. Bu türden evrak arasına mevzuat türünde düzenlenmiş evrak özellikle girmektedir. Mevzuat türü evraka sürekli başvuru ihtiyacı söz konusu olmakla birlikte, henüz yürürlükte olanlara ihtiyaç daha fazladır. Yürürlükten kaldırılanlara yönelik büro yaklaşımı ise yürürlükte olanlar gibi değildir. Bu yüzden, yürürlükte olmayan mevzuat türü evrakın -diğer türden evrak gibi- arşive devredilmesi gerekir. -Ancak bu noktada, kurum tarafından üretilen ve üst makamlar tarafından uygulanmak üzere gönderilen mevzuat türü evrakın ayrı ayrı değerlendirileceği açıktır.- Bu yöndeki düşüncelerini Celal Esad şöyle ifade etmiştir: "Bunlar içinde şûbenin her zaman mürâcaat etmesi icâb eden emîr, nizâmnâme, tamîm vesâire gibi şeyler mahzen-i evrâka irsâl edilmeyib şûbelerde muhâfaza olunur." (Celal Esad, 1331/1915, s. 18). Şubelerde ihtiyaca binaen tutulmaya devam eden evrakın tamamının mevzuat türünden olması gerekmez. Bunu, ilgili cümledeki "vesâire" ibaresinden anlamak mümkündür. Bürolarda mevzuat gibi sürekli başvuru ihtiyacı duyulacak bazı evrak grubunun arşive devredilmeyip bürolarda sürekli korunması günümüz büro uygulamalarıyla da örtüşmektedir.

\subsection{Arşiv (Mahzen-i Evrâk) İşlemleri}

\subsubsection{Düzenleme ve Evrakın Korunması İșlemleri}

Günümüz uygulamalarına göre, ayıklama imha sürecinden geçen ve tarihsel değere (araştırma değerine) sahip olan evrakın bir kısmı -saklama planına göre- üretildiği kurumda saklanır; diğer bir kısmı ise sürekli saklanmak üzere devlet arşivine transfer edilir. Arşive devredilen evrak, asli düzene sadık kalınarak koruma altına alınır. Arşive devredilen evrak eğer belli bir düzene sahip değilse, provenansına ve faaliyet alanlarına uygun şekilde düzenlenir ve nitelemesi yapılır. Ardından araştırmacıların mümkün olan en kolay şekilde yararlanmalarının önünün açılması amacıyla araştırma araçları hazırlanır. Örgüt çalışanlarından gelen bilgi istekleri için getirim (retrieval) hizmeti, araştırmacılara ise evraka erişim ve danışma hizmeti verilir. $\mathrm{Bu}$ hizmetin verilmesinin süreklilik kazanması için, evrakın korunduğu depoların uygun çevre şartlarına sahip olması gerekir. Günümüz bilgi ve büro teknolojilerinin verdiği geniş imkânla, bir kısım/bütün malzemenin mikrofilme alınması, çoğaltılması, dağıtılması ve bozulan evrakın onarılması (restorasyonu) bu bağlamda yapılacak diğer işlerdir (Ataman, 1992). Celal Esad 
ise yukarıda sayılan faaliyetlerin teknoloji ile ilgili olmayan kısımlarının tamamının yapılması yönünde fikir beyan etmiştir. Bütün bunlar aşağıda anlatılmaktadır. Celal Esad, evrakın arşivde (mahzen-i evrâk) korunması ve düzenlenmesi işlemlerine -kayıt işlemleri kadar olmasa dageniş bir yer ayırmıştır. Celal Esad'ın evrakın korunmasına ve tasnif işlemlerine dair önerdiği çözümler şu şekildedir:

\section{a) İşlemi tamamlanan evrakın sorumlu şubeye teslimi}

Celal Esad, işlemi tamamlanan evrak ile ilgili şu bilgileri vermektedir: İşlemi tamamlanan evrak, -genel kayıt işlemleri tamamlanmış olmak kaydıyla- ait olduğu büroya gönderilir ve arşive de bu büro tarafından teslim edilir. Bu silsileye uyulmaz ise işlemin ait olduğu şube, işlemin tamamlandığından haberdar olmaz ve kayda dair işlemin kapatılması için gerekli olan son muamele yapılmamış olur. Böyle bir durum, işlemden sorumlu şube tarafından, işleme dair ahvalin, akıbetin ve sürecin sorgulanmasını gerektirir. Muamelenin ideal anlamda yerine getirilmesi ise ilgili şubeyi, kendisine ait evrakı araştırma zahmetinden kurtarır. İşlemi yürütmekten sorumlu büro, -günümüzde de olduğu gibi- yürütmüş olduğu her işlemin akıbetinden haberdar olmuş olur (Celal Esad, 1331/1915, s. 19). Celal Essad bu yöndeki düşüncelerini şu ifadeleriyle anlatmıştır:

Bir şûbede muâmelesi hitâm bulan evrâk eğer kayd-1 umûmîden geçmiş ise evvelâ hangi şûbeye gitmiş ise o şûbeye iâde olunur. Kayd-1 umûmîden geçmeksizin şûbelerden dolaşarak gelmiş ise âid olduğu şûbeye iâde edilir ve mahzen-i evrâka o şûbe vâsıtasıyla gönderilir. Bu husûsa dikkat edilmeyecek olursa o işi gönderen şûbe muâmelenin hitâmından haberdâr olamayacağı ve kayıtlarının ilâ nihâye açık kalacağ tabiî olub, ay nihâyetinde şûbe tarafından sorulmak zahmetinden kurtarılmış ve şûbe-i âidesine işin ne sûretle neticelendiği hakkında malûmât verilmiş olur. Muâmelesi hitâm bulub aslı şûbenin kendisine âid olan evrâk ile şûbelerden yazılan tezkire ve derkenar müsveddeleri tekmîl teferruât ve melfûfâtıyla berâber mahzen-i evrâk teslîm defterine kayıd olunub imzâ mukâbilinde mahzen-i evrâka teslîm olunur. (Celal Esad, 1331/1915, s. 19).

\section{b) İşleme dair düzenlenen her evrakın bütün halde arşive teslimi ve ilk arşiv işlemleri}

İşlemi tamamlanan faaliyete dair üretilmiş ve ilk düzenlemeleri şube kayıt bürolarında yapılmış olan bütün evrak, yılsonu itibariyle -istisnalar hariç- toplu halde arşive transfer edilir. Bu faaliyet, Celal Esad tarafindan şu şekilde ifade edilmiştir: Evrak “[...] sene nihâyetinde takımıyla mahzen-i evrâka teslîm olunur." Bu da, muamelesi tamamlanan evrakın aslının yanı sıra, işleme dair tezkirenin, bütün derkenar müsveddelerinin ve eklerin toplu halde arşive teslim edilmesi gerektiği anlamına gelmektedir. Her şeyden önce, işleme dair dosya, arşiv kayı1t 
defterine kaydedilir ve imza karşılığında arşive teslim edilir. Arşiv memuru, bürolardan gelen evrakı imza karşılığında alır, arşive devir için gelen evrakı deftere kaydeder ve eksiksiz bir şekilde evrak müdürü veya onun yardımcısına teslim eder (Celal Esad, 1331/1915, s. 18, 20).

\section{c) Arşive teslim edilen evrakın incelenmesi ve kayıt numarasının verilmesi}

Arşiv memuru tarafından teslim alınan ve memur tarafından amirine teslim edilen evrak, öncelikle eksiksiz olması bakımından kontrol edilmelidir. Bu iş, evrak müdürü tarafından yapılır. Evrak müdürü, kendisine teslim edilen evrakı (dosyayı) önce inceler, ardından bir tasnif damgası vurur ve arşiv kayıt numarasını yazar (Celal Esad, 1331/1915, s. 19). Bu işlem, günümüzde sağlama (aksesyon) anlamına gelir ve işlem neticesinde oluşan listelere de sağlama listesi/kütüğü (aksesyon listesi) denir (Walne, 1995, s. 93-94).

\section{ç) Evrakın fonksiyon, dosya ve klasör ilişkisinin kurulması/korunması}

Günümüz uygulamalarında olduğu gibi, Celal Esad'ın önerdiği uygulamalarda da aynı şubenin evrakının birlikte düşünülmesi, aynı işleme ait evrakın toplu halde tutulması, bunların birbirinden ayrılmaması ve bu işlem için de belli araçlar kullanılması ön plandadır. Her şubenin işlem görmüş evrakı toplu halde takım (ana seri) olarak addedilmeli, farklı işlemlere ait evrak cüzler (klasör, gömlek) oluşturulacak şekilde birbirinden ayrı halde tutulmalı (ayrı cüzdan -dosya, hacimli zarf- içine konulmalı), aynı tür işlemin yürütülmesi sırasında üretilen muhtelif işlere ait evrak grubunun her biri ayrı cüzlere (klasör, gömlek) konulmak suretiyle tasnif edilmelidir. Her işlem, bütün ek ve diğer ayrıntılarıyla birlikte bir gömlek (iki kapaklı mukavva, ikiye kırılmış ve içine aynı işlem grubuna ait evrakın konulduğu kalın kâğıt) içine konulur ve böyle bir gömlek başlı başına bir cüz olarak addedilir. Her bir cüze bir numara verilir ve cüze verilmiş olan bu numara o işe ait genel kayıt numarası olarak değerlendirilir (Celal Esad, 1331/1915, s. 20). Celal Esad, bu durumu şöyle ifade etmiştir:

Şûbelerin her birine âid muâmelâtın kâffesi bir "takım" addedilib aynı şûbeye âid muhtelifü'l-cins muâmelât birer cüzdan ve aynı cins muâmelâta âid muhtelif işler de birer cüz olmak üzere tasnîf edilir. Her iş melfûfât ve teferruâtıyla beraber bir gömlek içine vaz' olunacağından başlı başına bir cüz teşkîl eder. O cüzün numarası o işin kayd-1 umûmî numarasıdır. Şehremâneti dâireleri teşkilât-1 hâzıraya göre âtideki takımlara ayrılabilir. (Celal Esad, 1331/1915, s. 20).

Bu açıklamalar, günümüzde belgeden fona giden arşivsel bağa işaret etmektedir. İyi bir dosya tasnif planı örgütün fonksiyonlarını gösterdiği gibi belgenin üretildiği vaka veya konu bağlamında doğru dosyayla ilişkilendirilmesine imkân verir. Böylece fonksiyonu açıklayan seri, alt seri, seri içerisindeki vaka yani müstakil iş anlaşılır. Vakaya göre açılan dosya içerisinde faaliyetlere göre föyler teşekkül eder. Föyde faaliyetin işlemlerini karşılayan belgeler bir küme oluşturur. Bu föyler iş bağlamında dosyayı meydana getirir. Arseven'in belirttiği bu durum, 
bir taraftan işlem, belge, föy ve dosya ilişkisine işaret ederken aynı zamanda belediyelerde dosyalamanın ve dosya bütünlüğünün önemini de açığa çıkarmaktadır.

\section{d) Kaynağa sadık kalınan bir dosya planının oluşturulması}

Celal Esad'ın kurum tarafindan üretilen evrakın düzenlenmesi konusuna bakışı günümüzden farklı değildir. Kurumsal teşkilat yapısını ve bu teşkilat yapısına bağlı fonksiyonların belirlenmesini, bu fonksiyonların da ana seri ve alt seriler meydana getirmesini, dosyaların da buralar altında toplanmasını önermektedir. Fonksiyonlara bağlı oluşturulan dosya grubunu takım yani ana seri olarak nitelendirmektedir. Celal Esad, bu bilgi ile yetinmemiştir. İstanbul Şehremanetinin örgütsel yapısına bağlı bir dosya şeması da önermiştir (Celal Esad, 1331/1915, s. 20, 23). Kendisi, bu tasnif uygulamasını İstanbul Şehremanetinin bir şubesi olan Kadıköy Şubesinin ihtiyacı için önermiştir. Ancak -şube ihtiyaçları dikkate alınarak- İstanbul Şehremanetinin diğer şubeleri için de pekâlâ uygulanabilir. Celal Esad, bu durumu şu şekilde ifade etmektedir: "Kadıköy Dâiresine göre tertîb edilmiş olan bu cedvel her şûbenin ihtiyâcâtına göre bi’t-tecrübe ta'dîl ve 1slâh dahi olunabilir.” (Celal Esad, 1331/1915, s. 23).

Şehremaneti tarafından yürütülmekte olan işler (muamelat), mevcut teşkilat yapısına göre Genel Yazı İşleri (Kitâbet-i Umûmî, 1. Takım), Fen İşleri (Heyet-i Fennîye, 2. Takım), Sağlık İşleri (Heyet-i Sihhîye, 3. Takım), Muhasebe (Heyet-i Hesâbîye, 4. Takım) ve İdari (5. Takım) olmak üzer beş ayrı takım (ana seri) halinde tasnif edilebilir. Bu takımlar ana konuları açıklarken kendi içinde alt konu (alt seri) başlıklarına ayrılmalıdır. Örneğin; Celal Esad'ın Kitâbet-i Umûmîye olarak ifade ettiği 1. Takım; kendi içinde 1) Memurîn, 2) Belediye ve mebûsân intihâbâtı, 3) Komisyonlar, 4) Muâmelât-1 askerîye, 5) İmtiyâzât ve mukâvelât, 6) Matbûât ve ilânât, 7) Eytâm, aceze ve muhtâcîn, 8) Posta ve telgraf ve telefon, 9) Muhâcirîn, 10) Emânet-i aliyyeden gelen emirler, 11) Müdîriyet emirleri, 12) İstimlâkât, 13) Muâmeleden müstağnî evrâk, 14) Şirketler muâmelât1, 15) Tebligât (eshâb-1 emlâk ve ahâlîye), 16) Dâvâlar, 17) Mektebler ve18) İstatistik olmak üzere on sekiz alt konuya ayrılmıştır. Az önce belirtilen beş şube haricinde başka bir şubenin daha olması halinde, onlar için de takımlar, diğer bir deyişle ana seriler oluşturulabilir. Şehremanetinin merkez büroları için oluşturulacak takımlar (ana seri), şehremanetinin teşkilatına ve büroların iş alanlarının tespiti ile oluşturulur. ${ }^{2}$ Örneğin; genel müfettişlik genel yazı işleri ile birlikte aynı takıma (ana seri) yerleştirilir. Şehremanetinin özel kalemi, kendi evrakını dosya dolaplarında bizzat muhafaza eder, ancak özel kalem, evrakını arşive indirmez; bu yüzden arşivde bu büroya özel bir takım (ana seri) açılmaz. Takımlara (ana seri) ait işlem, aynı işe dair bütün ayrıntılarını muhtevi olmak üzere cüzdanlara konulur; bu da, işlemin basit ve kapsamlı olmak üzere düzenlendiğini göstermektedir (Celal Esad, 1331/1915, s. 20-24).

2 Celal Esad, İstanbul Şehremaneti (Belediyesi) Kadıköy Şubesine ait bir dosya planı sunmuştur. Bu dosya planı, teşkilat yapısı dikkate alınarak beş grupta değerlendirilmiştir. Bu beş grup da, kendi içinde alt serilere ayrılmıştır (Seri ayrıntıları hakkında geniş bilgi için bkz.: Sümbül ve Keskin; 2018, s. 36-40; Sümbül ve Keskin, 2020, s. 116-122). 
Günümüzde yerli ve yabancı birçok bilim insanının kurumlarda -belgeleri düzenlerkentemel işlere yani ana konu olarak fonksiyonlara göre düzenlemenin esas alınması gerektiğini belirtirken, Arseven'in bir asır önce bu uygulamaları gündeme getirmesi dakkate şayandır. Eserde belediyenin örgütsel yapısına uygun bir dosya planı önerilmektedir. Belediyedeki örgüt yapısına ilişkin takımlar (ana seri) fen işleri, sağlık işleri ve muhasebe denilerek örgütün faaliyet gösterdiği temel ana konular kastedilmektedir. 1. Takım olarak ifade edilen Genel Yazı İşleri (Kitâbet-i Umûmî) ana konudur. Daha sonra açıklanan 1) Memurîn, 2) Belediye ve mebûsân intihâbâtı, 3) Komisyonlar, 4) Muâmelât-1 askerîye, vb. gibi başlıklar ise daha özel düzeyde temel fonksiyonlara karşılık gelmektedir. Dolayısıyla Celal Esad'ın yıllar önce dosya planlarında fonksiyonun gücünü ${ }^{3}$ açığa çıkarması dikkate şayan bir tespittir.

\section{e)Tasnif (düzenleme) ve kontrol işlemleri}

Günümüzde düzenleme ve kontrol işlemleri evrakın (dosyaların) arşive tesliminden önce ve belge yönetimi ve arşive devir işlemlerinin bir parçası olarak gerçekleştirilmektedir. Kurum arşiv çalışanlarının öncülük ettiği bir dizi faaliyet sonrasında kurum dosya planları ve bunun bir alt işlemi olarak da saklama planları oluşturulur. Kurumun tamamında üretilen evrakın düzenlenmesi yani işlemlere ait evrakın hangi dosyanın parçası olacağının kararının verilmesi işlemleri de, dosya planları doğrultusunda ancak büro çalışanları tarafından yerine getirilir. Evrakın uygunluk kontrollerinin yapılması ise evrakın arşive transferi sırasında yapılan bir iştir. $\mathrm{Bu}$ iş, birim personeli ile birim belge yöneticisi tarafından müştereken yerine getirilir (Devlet arşiv hizmetleri hakkında..., 2019, m. 13/1-4). Celal Esad, -bu anlatılanlardan neredeyse tamamen farklı olarak- düzenleme ve uygunluk kontrolü gibi mesleki faaliyetlerin arşiv yöneticisi ve çalışanları tarafından yerine getirilmesi gereken bir iş olduğu üzerinde durmaktadır. Arşive indirilen evrakın uygunluk kontrolü ve tasnifi evrak müdürü ve tasnif memuru tarafından yapılmaktadır. Evrak müdürü ve tasnif memuru, her ikisi birlikte, evrakı takımına (an aseri) uygun olarak ayırır, tasnif fihristine göre evrakın hangi cüzdan içinde yer alması gerektiğine karar verir, tasnif damgası üzerine cüzdan numarasını yazar ve tasnif memuruna gönderir.

Evrâk müdîrinden gelen evrâk tasnîf memûrları tarafından takım takım ve cüzdân cüzdân ayrılarak her cüzdâna âid olan muhtelif işler de birer birer ayrı kablar içine vaz‘ olunduktan sonra mahzen-i evrâk kâtibleri tarafindan üzerlerine îcâb eden numero ve hülâsalar yazılarak dikilir ve ipliğin iki ucuna bir mühür pulu yapışdırılır. (Celal Esad, 1331/1915, s. 23).

Evrak müdürü ayrıca, evrakın ek ve müsveddeleri ile muamele numaralarında bir eksiklik ve düzensizlik olup olmadığını kontrol eder. Tasnif memuru ise evrakın faaliyete uygun şekilde ilgili dosyalara konulup konulmadığını değerlendirir, uyuşmuyorsa yeni bir numara açar ve

3 Fonksiyonun gücü hakkında daha geniş ve güncel bilgi için Niyazi Çiçek (2007, 238-242) tarafından hazırlanmış olan çalışmaya bakılabilir. 
yeni konuyu belirler. Evrak müdüründen gelen evrak, tasnif memuru tarafından faaliyet alanına ve işlem ilişkisine göre ayrılır. Her işlem (işleme ait evrak grubu) için ayrı dosya gerekir. Ardından arşiv (mahzen-i evrak) kâtipleri tarafından bunların üzerine numarası ve özetleri yazılır, dikilir ve ipliğin iki ucuna bir mühür pulu yapıştırılır. Daha sonra diğer memurlardan biri tarafından ana seriler (takım) cüzdanlara (dosya, hacimli zarf) ve işlem gruplarına (cüz) göre ayrılır ve bir gömlek içine yerleştirilir. Diğer kâtipler de, bunların üzerlerine yazılarını yazar. Ardından cilt memuru bu gömlekleri çözülmeyecek şekilde diker ve üzerlerine birer kâğıt pul yapıştırır. Bu cüzlere ayrıca bir dış kapak (cüz kapağı) geçirilir; bu kapakla birlikte dikilir ve mühürlenir. Her cüzün arkasında, o cüzde kaç yaprak olduğu yazılır. Bütün bu işler şu şekilde ifade dilmiştir:

Evrâk müdîri evvelâ evrâkı takım itibariyle tefrîk ve ba'dehû bâlâdaki tasnîf fihristinde mevcûd işlerin sınıfına göre hangi cüzdana girmesi icâb edeceğini tayîn ile tasnîf damgası üzerine bu rakamları tahrîr ederek tasnîf memûrlarına gönderir. [...] memûrlarından biri takımları ayırır ve yanındakine verir, o da her takıma âid cüzleri ayırır, birer gömlek içine kor ve diğer kâtibler tarafından yazıları yazılır. Bu kâtiblerin adedi bi’t-tabî işin az veya çok olmasına göredir. Gömlekler bu sûretle hazırlandıkdan sonra [...] cild memûru gelir, bunları alarak dike[r] ve üzerlerine birer kâğıd pul yapışdırır. (Celal Esad, 1331/1915, s. 23-24).

Bunun altı evrak müdürü, onun olmaması halinde arşiv başkâtibi tarafından imzalanır. Dikilen cüzler, numara tasnif defterine kaydedildikten sonra genel kayda gönderilir. Numara fihrist defterinin işlevi, “[...] şûbelerden kayd-1 umûmî numarasıyla bir iş arandığı vakit onun hangi takım (ana seri), hangi cüzdan ve hangi cüz dâhilinde bulunduğunu derhâl bulmağa hizmet etmekdir." (Celal Esad, 1331/1915, s. 25). Genel kayıt esas defterinin sol tarafinda arşive ait haneler vardır. Bu hanelere, evrakın takım, cüzdan (zarf, dosya) ve cüz (klasör) numaraları kaydedilir. Ardından aynı zamanda gömlek olarak addedilen cüzler ait oldukları cüzdan içine yerleştirilir. Cüzdanın üstüne ve iç tarafına içeriği ve esas numaraları yazılır. Genel kayıt defterleri, arşiv defterleri ve arşiv cüzdanları, on yıl muhafaza edilir. Onbir senelik olanlar eski evrak deposuna (kurum arşivi, evrâk-1 atîka mahzeni) transfer edilir. Buradaki defter ve dolaplar sene ve takım sırasıyla, yani fonksiyon esasına sadık kalınarak ve kronolojik olarak tasnif edilir (Celal Esad, 1331/1915, s. 23-27). Bu konudaki ifade şu şekildedir: "Evrâk-1 atîka mahzeninde dahi gerek defterler ve gerek dolablar sene ve takım sıralarıyla tasnîf olunur." (Celal Esad, 1331/1915, s. 27).

\section{f) Arşive belge transferi}

Genel kayıt bürosunun ve birim arşivinde korunan (mahzen-i evrâk) defter ve cüzdânları (dosya, zarf) on yıl kadar muhafaza edilir. Genel kayıt bürosuna ve birim arşivine (mahzen-i evrâk) ait defter ve cüzdânlar, birim arşivlerinde on y1l korunduktan sonra, on birinci yıl (on 
birinci yılında olan defter ve cüzdanlar) kurum arşivine (evrâk-1 atîka mahzeni) transfer edilir. Celal Esad, bu durumu şu şekilde ifade etmiştir: "Gerek kuyûd-1 umûmîye ve gerekse mahzen-i evrâkın defter ve cüzdânları onar sene muhâfaza olunub on bir senelik olanlar her sene birer birer evrâk-1 atîka mahzenine nakl olunur." (Celal Esad, 1331/1915, s. 27).

\subsection{Arşivden (Mahzen-i Evrâk) Evrak Talebi}

Arseven, kitabında arşivden belge talebini -modern büro ve bilgi teknolojilerinin sağladığı imkânlar hariç- günümüz kurallarına uygun şekilde düşündüğü anlaşılmaktadır. Öncelikle evrakın arşivden talep edilmesi, bunun için de matbu talep formunun (pusula) doldurulması gerekmektedir. Bu talep formu üzerine belgenin genel kayıt numarası, işin özeti veya belgeye ait bilgi/ayrıntı yazılır ve form arşive ulaştırılır. Talep formu; dip koçanı, sağ ve orta kısım olmak üzere üç parçadan oluşur. Dip koçanı arşivde kalır, diğerleri gönderilir. Arşivden evrakın dışarı çıkartılması ancak talep formu ile gerçekleşir. Yetkili onayından sonra yerinden çıkartılan evrak için formun orta kısmı -evrak yerine geçmek üzere- cüzdân içine konulur. Bundan sonra evrak talep sahibine/talep eden büroya teslim edilir. Büro, evrak üzerinde araştırmasını tamamladıktan sonra arşive iade eder; iade edilen evrak çalışanlar tarafından arşivde kontrol edilir; bir eksiklik yoksa yerine yerleştirilir. Evrak yerine kaim olan pusula kısmı, evrak yerine konulduktan sonra alınır ve ayrı ber yerde korunur (Celal Esad, 1331/1915, s. 27-29). Ayrıntıl1 ve uzun süreceği izlenimi veren bu süreç, “[...] evrâk ve dosyaların tedkîk veya tahrîf veya tebdîli veyâhûd bazı vesâikin çıkarılması, gizlice tashîhât yapılması gibi sûiistimâlâtın önünü almak için elzemdir.” (Celal Esad, 1331/1915, s. 29). İncelenmek üzere alındığı bürolarda evrakın bir haftadan fazla tutulmaması gerekir. "Hiçbir cüz ve dosya kitâbet-i umûmîyenin izni olmaksızın tedkîk için şûbede bir haftadan fazla alıkonulamaz. Bu müddetden fazla kalan dosyaların cedvelini mahzen-i evrâk tanzîm ile şûbelerinden taleb eder ve bu cedveli müdiriyet veya makâm-1 emânete takdîm eyler." (Celal Esad, 1331/1915, s. 29). Ödünç alınan evrak hakkında bir liste tutulması özenle takip edilmesi gereken bir işlemdir. Bu da, yazar tarafından şu şekilde ifade edilmiştir: "Evrâk ve vesâik zâyi' olduğu takdirde müsebbib ve mesulleri hakkında kânun-1 cezânın (126)ıncı maddesi tatbîk olunur.” (Celal Esad, 1331/1915, s. 29).

\section{SONUÇ}

Celal Esad Arseven, son dönem Osmanlı ve erken dönem Cumhuriyet aydınları arasındadır. Temelde askerlik mesleğine mensup bir kişi olmakla birlikte, bu meslekten erken bir zamanda ayrılmış, bir ara yurt dışında (Paris, Fransa) bulunmuş, sivil hayata hızlı uyum sağlamış, çeşitli

4 Kanûn-1 Ceza'nın ilgili maddesi şu şekildedir: "Devletce evrâk-1 mühimme ve senedât ve cerîde ve defâtîr ve muhâkemâta dâir olan kağıdlar muhâfazalarına mahsûs olan mahallerden veyâhud muhâfazasına memûr olan âdemlerin ellerinden ahz ve sirkat olunur veyâ mahv ve telef etdirilirse bu keyfiyet muhâfazasına memûr olanların adem-i tekayyüd ve teseyyüblerinden neşet ettiği mütehakkik oldukda bir aylık maaşı mikdârı cezâ-yı nakdî alınır ve bir haftadan üç aya kadar habs olunur" (Kanun-1 Cezâ, Düstur, 1289, 1. Tertib 1. Cild madde 126, s. $565)$. 
kamu dairelerinde ve farklı pozisyonlarda çalışmış, bunların yanı sıra çok farklı alanlarda birçok eser kaleme almıştır. Bu eserlerden biri de, hacmi nedeniyle bir risale özelliğine sahip olan Belediyelerde Evrâkın Kayıd ve Tasnîfi Nasıl Olmalıdır? başlığını taşımaktadır. Söz konusu eser; genel anlamda arşivciliği, özelde ise belediye arşivciliğini ele almaktadır. Belediye arşivciliği, İstanbul Şehremânetinde/Belediyesinde ve İstanbul Şehremâneti/Belediyesi Kadıköy Şubesinde/Dairesinde yürütülen uygulamalar anlatılarak modellenmiştir. Eserde evrakın kayıt ve korunması işlemleri, dosyalama, dosya planları, fonksiyona göre düzenleme, bürolardan arşive devir ile arşivde yapılacak işler ve ödünç işlemleri konusu anlatılmaktadır. Eserde verilen dosyalama örnekleri ise tamamen Kadıköy Dairesi/Şubesi özelinde hazırlanmıştır ve diğer şubeler için de örnek teşkil edebilecek temel özellikler taşımaktadır. Bu da, bu kadar sistemli ve ayrıntıya inen açıklamalarıyla incelenen bu çalışmanın Osmanlı sınırları içinde arşivcilik hakkında kaleme alınmış en önemli ve kapsamlı eser olabileceğini göstermektedir.

Belediyelerde Evrâkın Kayıd ve Tasnîfi Nasıl Olmalıdır? adlı eser, yazarın da ifade ettiği üzere, belediyelerde evrakın kayıt, koruma, arşiv ve ödünç evrak işlemleri hakkında bilgi vermek üzere hazırlanmıştır. Belediyelerde yapılan arşiv çalışmaları kitapta odak noktayı oluşturmakta olup, uygulamalara ilişkin birçok konu açıklanmıştır. Bürolarda üretilen evrakın kayıt, koruma, düzenleme, dosyalama, arşive devir, arşiv süreçleri ve arşivden ödünç talep işlemleri konuları üzerine açıklayıcı bilgi verilmektedir. Dosyalama konusunu ele alırken, dosya planının belediyelerin ana serileri ile bunlar altında yer alan fonksiyonlara göre yapılması gerektiğini belirtmesi oldukça dikkat çekici olmuştur. Yüzyılı aşan bir zaman öncesinden bugün de hâlâ geçerliliğini koruyan bir tasnif mantığını ortaya koyması, Türk arşivcilik geleneği için göz ardı edilemeyecek önemdedir. Bununla birlikte, eserin giriş kısımlarında kayıt ve evrakın korunması işlemlerinin, dolayısıyla arşivin önemi üzerinde durulmuştur. Celal Esad, birçok konuda geniş açıklamalara yer verdiği eserinde arşivlerde imha konusu gibi bir alana temas etmemiştir. Eser içinde, işlemlere ait form örnekleri, kayıt ve arşiv memurları ile yöneticiler için düzenlenmiş bir yerleşim krokisi ve bir de İstanbul Belediyesi için düşünülmüş "alamet” (sembol, logo) yer almaktadır.

Evrakın kayıt işlemleri, büro işlemleri ve arşiv işlemleri hakkında yazar tarafından eser içinde beş temel başlık (bölüm) oluşturulmuştur. Bu başlıklar; evrakın kayıt ve tasnifi, genel kayıt, şubelerde kayıt, arşiv ve evrak talebi işlemleri şeklindedir. Bununla birlikte, eser içinde dikkat çeken temel alt başlıklar da mevcuttur. Birinci bölümün derkenar şeklinde belirlenmiş başlıkları; 1) kayıt ve evrakın korunmasının lüzumu ve önemi, 2) düzenli kayıt usulü ve tasnifin uygulanmasındaki zorluklar ve 3) kâğıtların hacim ve şeklinde birlik (standart) konularına ayrılmıştır. İkinci, üçüncü ve beşinci bölümlerin alt başlıklara ayrılması tercih edilmemiştir. Dördüncü bölüm, sadece bir alt başlığa ayrılmıştır. Yazar, bu başlıklar içinde yapılan işlerin ne tür bir yönetici ve memur tarafından yerine getirildiği, bu yöneticinin ve memurun unvanı, yetkileri, sorumlulukları, nitelikleri, mesleki terminoloji, kullanılan malzemenin yanı sıra yazı 
işleri, büro ve arşiv pratiklerinin nasıl yerine getirileceği konularına temas etmiştir. Yazar bütün bunları kavramlaştırmış veya zaten o dönemde kullanılmakta olan mesleki terminolojiler olarak dikkatimize sunmuştur. Dolayısıyla, bir Osmanlı kurumunda (İstanbul Şehremaneti) büro ve arşiv işlemlerinin ne olduğu, döneminde kullanılan kavramlar, mesleki icra yetkisine sahip görevliler, kullanılan ekipman ve yapılan işlemler hakkında eser içinde serpiştirilmiş şekilde bilgiler bulmak mümkündür.

Celal Esat Arseven'in tarafımızdan incelenen eseri, literatürde İkinci Dünya Savaşı sonrasında geliştiği genel kabul görmüş olan ancak Birinci Dünya Savaşından sonra, özellikle de İkinci Dünya Savaşı yıllarında çok daha belirgin hale gelen kurumlarda biriken evrak yığını sorununa erken bir dönemde çözüm üretmek için geliştirilen belge yönetimi iş ve işlemlerinin (Evans, 1982, s. 15; Schellenberg, 1993, s. 30-31; Bradsher, 1988, s. 34-35; Yalçın, 2007, s. 41), aslında son dönem Osmanlı kurumlarında çoktan uygulandığını -veya en azından uygulanmaya çalışıldığını- göstermiştir. Bu haliyle eser, bir anlamda Osmanlı yerel yönetimlerinde üretilen belge ve arşiv süreçleri hakkında hazırlanmış bir el kitabı niteliğini taşımaktadır. Şu halde, modern anlamda yüzyıllardan beri belirgin bir arşiv geleneğine sahip oldukları bilinen Türk devletlerinde belge yönetimi geleneğinin de belirgin bir temele sahip olduğu söylenebilir. Yine bu eser, Türk belge yönetimi geleneğinin Türkiye Cumhuriyeti'nden önce başladığını ispat eden önemli bir delildir. Bununla birlikte Celal Esad, belge ve arşiv yönetimi iş ve işlemlerine ilişkin önerilerini önemli ölçüde Fransa örneğinden, özelde ise Paris Belediyesi uygulamalarından -İstanbul Şehremaneti bu örneğe göre kurulmuştur- hareketle sunduğu hatta bir süre kaldığ Paris deneyimlerine ve zaten evrak müdürü olarak görev yaptığı İstanbul Belediyesi (Şehremaneti) Kadıköy Şubesinde edindiği tecrübelerine dayandırdığı açık bir dille ifade edilebilir. Tahlil edilmeye çalışılan Belediyelerde Evrâkın Kayıd ve Tasnîfi Nasıl Olmalıdır? adlı eser, tarihin tozlu raflarına gizlenmiş muhteşem bir devlet gelenek ve medeniyetini gün yüzüne çıkaracak daha pek çok hazineler olduğunu ayrıca bir kez daha gözler önüne sermiştir.

Teşekkür: Çalışmaya verdiği önemli katkıları için Prof. Dr. Niyazi ÇİÇEK, Prof. Dr. Bilgin AYDIN ve Dr. Yaşar DEMİR'e teşekkürlerimizi sunarız.

Hakem Değerlendirmesi: Dış bağımsız.

Çıkar Çatışması: Yazarlar çıkar çatışması bildirmemiştir.

Finansal Destek: Yazarlar bu çalışma için finansal destek almadığını beyan etmiştir.

Peer-review: Externally peer-reviewed.

Conflict of Interest: The authors have no conflict of interest to declare.

Grant Support: The authors declared that this study has received no financial support. 


\section{Kaynakça/References}

Anameriç, H. (2010/a). Kurum arşivi olarak belediye arşivleri. Yerel Yönetim ve Denetim, 15(11), 8-13.

Anameriç, H. (2010/b). Belediyelerde arşivin önemi. Beklenen Mahalli İdareler Dergisi,20(194), 7-12.

Anameriç, H. ve Rukanc1, F. (2006). Evrak-1 atikanın suret-i tasfiyesine dair rapor. Belgeler, 27(31), 91-111.

Arşiv Mekanlarının Düzenlenmesi. (2006). TS 13212.

Ataman, B.K. (1992). Karar verme mekanizmasındakiler için evrak işletmeciliği. Management thinking: Management club workshop papers and proceedings içinde (s. 1-6). İstanbul: Marmara Üniversitesi. ed. (II-IV 1992): 1-6. Erişim adresi: http://www.tcswat.org/bka/Articles/RM_fayda.html

Belediye Kanunu (mülga). (1930). Resmi Gazete, 14 Nisan 1930, Kanunun sayss1: 1580, Kabul tarihi: 3/4/1930.

Belediye Kanunu. (2005). Resmî Gazete: Tarih: 13/7/2005 Kanun Numaras1: 5393 Kabul Tarihi: 3/7/2005 Yayımlandığı Sayı: 25874 Yayımlandığı Düstur: Tertip: 5, Cilt: 44.

Büyükşehir Belediyesi Kanunu. (2004). Resmi Gazete: Tarih: 23/7/2004 Sayı:25531, Kanun Numarası: 5216 Kabul Tarihi: 10/7/2004.

Bloom, J.M. (2003). Kâğıda işlenen uygarlık. Kâğıdın tarihi ve İslam dünyasına etkisi. Çev. Zülal Kıllıç, İstanbul: Kitap Yayınevi.

Celal Esad. (1331/1915). Belediyelerde evrâkın kayıd ve tasnîfi nasıl olmalıdır. İstanbul: Ahmed İhsan ve Şürekâsı Matbaacılık Osmanlı Şirketi.

Çiçek, N. (2003). Kamu yönetiminde üretilen belgelerin form özelliklerinin incelenmesi ve arşivcilik açısından değerlendirilmesi (Yayımlanmamış doktora tezi). Marmara Üniversitesi, İstanbul.

Çiçek, N. (2007). Dosya tasnif planlarında fonksiyonun gücü. Değişen Dünyada Bilgi Yönetimi Sempozyumu, -Uluslararası Sempozyum Bildirileri- 24-26 Ekim 2007 içinde (235-244). S. Kurbanoğlu, Y. Tonta ve U. Al (Yay. haz.). Ankara: H. Ü. Edebiyat Fakültesi Bilgi ve Belge Yönetimi Bölümü.

Çiçek, N. (2008). Belediyelerde standart dosya planı uygulamalarında yaşanan güçlükler, Bilgi Dünyası, 9(2), 466-504.

Çiçek, N. (2018). Kurumsal bilgi ve belge yönetimi. Kurumsal iletişim, belge türleri, e-yazışma, elektronik belge yönetimi, dosyalama işlemleri. İstanbul: Marmara Belediyeler Birliği.

Çiçek, N. ve Bozlağan, R. (2008). Yerel yönetim birliklerinde belge yönetimi programı: Marmara ve Boğazları Belediyeler Birliği örneği. Akademik İncelemeler, 3(2), 189-222.

Delmas, B. (1991). Arşivler. Çev. Nihal Somer, Ankara: Devlet Arşivleri Genel Müdürlüğü Cumhuriyet Arşivi Dairesi Başkanlı̆̆ı.

Devlet arşiv hizmetleri hakkında yönetmelik. (18.10.2019). Resmî Gazete, Sayı: 30922.

Diyarbekirli, N. (1972). Türk sanatının büyük kaybı Celal Esad Arseven. Türk Kültürü, 10(113), 31-42.

Evans, F.B. (1982). Development of the archives and records management programme: Malasia (mission). Paris: United Nations Educational, Scientific and Cultural Organization.

Eyice, S. (1972). Celal Esad Arseven (1875-1971). Belleten, XXXVI(142), 173-201

Eyice, S. (1991). Celal Esat Arseven. Türkiye Diyanet Vakfi İslâm Ansiklopedisi (DİA) (Cilt. 3, s. 397-399) içinde. İstanbul: Türkiye Diyanet Vakfi.

Hayreddin Nedim. (1326/1910). Vasâik-i târîhiye ve siyâsîye tetebbuâtı. C. I-V, Dersaadet: Ahmet İhsan ve Șürekâs1. 
Hayreddin Bey [Nedim Göçen]. (2008). Belgelerin dilinden Osmanlı ve Avrupa (Vesâik-i târihiyye ve siyâsiyye tetebbuâtr), İshak Keskin ve Ali Ahmetbeyoğlu (Eds.), İstanbul: Selis Kitaplar.

Hildesheimer, F. (1997). Les Archives de France. Mémoire de l'Histoire, Paris: H. Champion.

İpşirli, M. (1995). Osmanlılarda kitâbet-i resmiyyeye dair eserler hakkında bazı gözlemler. Osmanlı-Türk Diplomatiği Semineri içinde (s. 1-8). İstanbul: İ.Ü. Edebiyat Faküt-ltesi.

İshakoğlu, Ö. (2009). “İbnü's-Sayrafî̀ ve el-Kânûn fî Dîvâni’r-Resâil Adlı Eseri”, Hidayet Lavuz Nuhoğlu Armağanı (s. 221-243) içinde, İstanbul: Pamuk Yayınları.

Karakaş, H.S., Rukancı, F. ve Anameriç, H. (2009). Belge yönetimi ve arşiv terimleri sözlüğü. Ankara: Devlet Arşivleri Genel Müdürlüğü.

Kallek, C. (1998). Hisbe. Diyanet İslam Ansiklopedisi içinde (ss. 133-143). Cilt XVIII, İstanbul: Türkiye Diyanet Vakfi.

Kanun-1 Cezâ, Düstur. (1289). 1. Tertib 1.

Kazıc1, Z. (1992). Belediye -Osmanlı Devleti-. Diyanet İslam Ansiklopedisi içinde (ss. 143-145). Cilt V, İstanbul: Türkiye Diyanet Vakfi.

Keskin, İ. (2007a). Mezopotamya'da arşivler ve arşivcilik. Mezopotamya ekseninde eski Önasya 'nın erşivsel düzenleme sistemleri. İstanbul: Çantay Kitabevi.

Keskin, İ. (2007b). Osmanlı arşivciliğinin teorik dayanakları hakkında. Türk Kütüphaneciliği, 21(3), 271-303.

Keskin, İ. (2008/a). Bir disiplin olma sürecinde arşivcilik. Arşiv Dünyası, 11, 3-8.

Keskin, İ. (2008/b). Günümüz arşivcilik anlayışıyla bir Osmanlı aydını olarak Hayreddin Bey [Nedim Göçen]'in (1867-1942) arşivcilik anlayışının karşılaştırılması. Journalof Turkish Studies -In Memoriam Şinasi Tekin III-, 32/1, 289-306.

Keskin, İ. (2013). Şehir arşivleri için yerel tarih yazımında yararlanılabilecek kaynakların seçimi ve sağlanması kriterleri: Konya ili örneği. II. milletlerarası şehir tarihi yazarları kongresi (s. 594-610) içinde. Konya: Konya Büyükşehir Belediyesi.

Keskin, İ. ve Günalan, R. (2011). Hayreddin Nedim Bey'in [Göçen] kaleminden arşivcilik. Yücel Dağll anısına (s. 332-353) içinde. Evangelia Balta, Yorgos Dedes, Emin Nedret İşli, M. Sabri Koz (Eds.). İstanbul: Turkuaz.

Keskin, İ. ve Kutluoğlu, M. H. (2013/a). Eski Mısır medeniyetinde arşivcilik. Prof. Dr. Erdoğan Merçil'e armağan (s. 461-497) içinde. Muharrem Kesik, Cihan Piyadeoğlu, Emine Uyumaz, Aydın Uslu, (Eds.), İstanbul: Bilgi Kültür Sanat.

Keskin, İ. ve Kutluoğlu, M. H. (2013/b). Hellenistik dönem Grek arşivciliği üzerine bazı notlar. Osmanlı 'nın izinde. Prof. Dr. Mehmet İpşirli armağanı (Cilt. 2, s.177-204) içinde. Feridun M. Emecen, İshak Keskin ve Ali Ahmetbeyoğlu (Eds.), İstanbul: TíMAŞ.

Keskin, İ. ve Kutluoğlu, M. H. (2015). Eski İran medeniyetinde arşivler ve arşiv uygulamaları. İsmet Binark armağanı içinde (s. 225-262). Yay.haz. İshak Keskin, Şekibe Nihal Somer ve Nizamettin Oğuz, İstanbul: Türk Edebiyat Vakfi.

Kutluoğlu, M.H. (1998). İngiliz Devlet Arşivi (PRO) ve yakın dönem Osmanlı tarihi açısından önemi. Osmanlı Araştırmaları, XVIII, 225-238.

Kütükoğlu, M.S. (2018). Osmanlı belgelerinin dili (diplomatik). Ankara: Türk Tarih kurumu.

Mehmed Hayati ve Osman Nuri. (1332/1914). Evrâk-ı atîkanın sûret-i tesviyesine dâir rapor. Dersaadet: Matbaa-i Arşak Garoyan. 
Menne-Haritz, Angelika. (2006, 10 Şubat). Dynamic Knowledge in Organizational Environments. Some Ideas on Knowledge Management. Erişim adresi: http://a.menne-haritz.bei.t-online.de/webtexte/word/dynknm.doc

Odabaş, H. (2001). Kurumsal iletişim açısından yazışmalar ve ülkemizde yazışmaların durumu. 21. yüzyıla girerken enformasyon olgusu sempozyumu bildirileri içinde (ss. 158-172).Ankara:TürkKütüphanecilerDemeği.

Ortaylı, İ. (1992). Belediye. Diyanet İslam Ansiklopedisi içinde (ss. 398-402). Cilt V, İstanbul: Türkiye Diyanet Vakfi.

Osman Nuri [Ergin]. (1922/1338). Mecelle-i umûr-ı beledîye: Târîh-i teşkilât-ı beledîye. Cilt I, İstanbul: Matbaa-i Osmaniye.

Özdemirci, F. ve Odabaş, H. (2005). Yazışma yönetimi ve dosyalama işlemleri. Ankara: Alter Yayıncılık.

Paul, K.D. (1988). Archivists and records management. Managing archives and archival institutions içinde (s. 34-52). James Gregory Bradsher. (Ed.). Chicago: University of Chicago Press.

Penn, I.A. ve dig. (1989). Records Management Handbook, London: Gower Publishing Ltd.

Posner, E. (1972). Twelfth century job descriptions for the registrar and the archivist of the Fatımid State chancery in Egypt. Mitteilungen des österreichischen Staatsarchivs, 25, 25-31.

Posner, E. (1998). Ortaçağ İslam dünyasında arşivler. Kütüphanecilik Dergisi, Ahmet Oğuz İcimsoy (Çev.). 4, 201-231.

Resmî yazışmalarda uygulanacak usul ve esaslar hakkında yönetmelik. (9 Haziran 2020). Cumhurbaşkanı Kararının Tarihi: 9/6/2020 Sayısı: 2646 Yayımlandığı Resmî Gazetenin Tarihi: 10/6/2020 Sayısı: 31151

Rumschöttel, H. (2008). Bilimsel bir disiplin olarak arşivciliğin gelişimi. İshak Keskin (Çev.), Arşivcilik metinleri (s. 11-29) içinde. İshak Keskin (Ed.), İstanbul: Yeditepe. Rumschöttel, H. (2000). "Die Entwicklung der Archivwissenschaft als wissenschaftliche Disziplin. Archivalische Zeitschrift, 83, 7-21.

Schellenberg, T.R. (1993). Arşiv idaresi. Çev. Neclâ İlemin, Ankara: Devlet Arşivleri Genel Müdürlüğü Cumhuriyet Arşivi Daire Başkanlığı.

Sümbül, S. ve Keskin, İ. (2018). 'Belediyelerde evrâkın kayıd ve tasnîfi nasıl olmalıdır' adlı eser ve Türk arşivciliği için önemi. Arşiv Dünyası, 20, 23-47.

Sümbül, S. ve Keskin, İ. (2020). Osmanlı aydınlarının bilgi ve belge yönetimi çalışmaları. Celal Esat Arseven 'in arşivcilik ve kütüphanecilik mesleklerine katklları. İstanbul: Hiperlink.

TODAİE (Türkiye ve Orta Doğu Amme İdaresi Enstitüsü). (1992). Kamu yönetimi araştırması, yerel yönetimler araştırma grubu raporu. Ankara: TODAİE Yayınları.

Walne, P. (1995). Arşivcilik Terimleri Sözlü̆̆̈̈. Türkçeye çeviren ve genişleten Bekir Kemal Ataman, İstanbul: Librairie de Péra.

Yalçı, H. (2007). Küçük ve orta ölçekli işletmelerde belge yönetimi (Yayımlanmamış yüksek lisans tezi). Hacettepe Üniversitesi, Ankara.

Yazıcı, N. (2009). Türkiye'de sanat tarihinde ilkler/öncüler. Türkiye Araştırmaları Literatür Dergisi, 7(14), 571-608. 


\section{EK: Terimler Listesi}

Not: Eser içinde kullanılan kavramlar ve açıklamaları listesi. Bu listede; yazar tarafından verilen kavramlar alfabetik olarak sıralanmış ve döneminin imlasına göre yazımları tercih edilmiştir. Yine verilen bilgiler, sadece metin içinde sahip olduğu anlam üzerinden değerlendirilmiştir.

\begin{tabular}{|c|c|}
\hline Terim & Açıklama \\
\hline Alâmet & İşaret, marka, sembol, logo. İstanbul Şehremanetinin/Belediyesinin alameti, logosu. \\
\hline Başkâtip & $\begin{array}{l}\text { Evrak kayıt bürosu kâtiplerinin en kıdemli/yetkili olanı; kayıt memurunun işini zaman } \\
\text { zaman yüklenen kıdemli kâtip. }\end{array}$ \\
\hline Belediye & İstanbul Şehremaneti/Belediyesi. \\
\hline Cüz & $\begin{array}{l}\text { Aynı muamelata ait evrak grubu, gömlek, klasör. Küçük belge grupları için kapak } \\
\text { işlevi gören karton veya kalın kağıttan yapılmış katlı yaprak.. }\end{array}$ \\
\hline Cüzdân & $\begin{array}{l}\text { Şubelerin farklı işlemlerine ait evrakın içine konulduğu araç; büyük boy ve hacimli } \\
\text { zarf, dosya. }\end{array}$ \\
\hline Cüz kapağı & $\begin{array}{l}\text { Cüzlerin (gömlek) dışını sarmak/kaplamak üzere dış kapak şeklinde hazırlanan kalın } \\
\text { kâğıttan yapılmış katlı yaprak. Bu kapak içindeki cüz ve evrakı kapatacak şekilde bir } \\
\text { bağ ile bağlanır. }\end{array}$ \\
\hline Cüz dış kapağı & $\begin{array}{l}\text { Cüzlerin (gömlek) dışını sarmak/kaplamak üzere dış kapak şeklinde hazırlanan kalın } \\
\text { kâğıttan yapılmış katlı yaprak. Bu kapak içindeki cüz ve evrakı kapatacak şekilde bir } \\
\text { bağ ile bağlanır. }\end{array}$ \\
\hline Çift yaprâklı kâğıd & $\begin{array}{l}\text { Uygun ebattaki bir kâğıdın ikiye kırılması suretiyle oluşturulan iki ayrı yaprak (dört } \\
\text { sayfa) üretilmesiyle oluşturulan kâğıttan bilgi taşıyıcısı. Bu yazı birimine; gerektiğinde } \\
\text { aynı usulle ancak ikincisinin ilkine yapıştırılması/dikilmesi yöntemiyle yeni sayfa } \\
\text { ilaveleri yapılabilir. }\end{array}$ \\
\hline Dâire & Kamu hizmeti gören kurum, kamu kurumunun birinci dereceden alt birimi. \\
\hline Dâire-i resmîye & $\begin{array}{l}\text { Kamu hizmeti gören resmi kurumlar. İstanbul Belediyesi. İstanbul Belediyesinin } \\
\text { şubeleri/daireleri }\end{array}$ \\
\hline Dâire-i beledîye & Belediyenin bir alt derece yönetim birimi. \\
\hline Dâire postacısı & Kurum dairelerinde evrakın alınıp-götürülmesinden sorumlu memur. \\
\hline Defter & $\begin{array}{l}\text { Evrakın kurum, daire, büro tarafından kayıt altına alınması sırasında kullanılan ve } \\
\text { sayfalardan mürekkep ciltli bütün. }\end{array}$ \\
\hline Derkenâr & $\begin{array}{l}\text { Faaliyet sırasında üretilen belgenin yazı alanının yan taraflarına (kenarlarına) işlem } \\
\text { için gönderildiği diğer bürolar tarafından düşülen not. }\end{array}$ \\
\hline Dolab & Evrak ve dosyaların konulması için tahsis edilen araç, raflı dolap. \\
\hline Dosya & Birbiriyle işlem ve konu ilişkisi olan evrakın içine koyulduğu araç. \\
\hline Encümen kararı & İstanbul Belediyesi (Şehremini) encümeni tarafından alınan kararlar. \\
\hline Erbâb-ı mesâlih & Sorun sahipleri. Kamu dairesine sorunlarını iletmek üzere dilekçe veren şahıs \\
\hline Esas kayıd defteri & $\begin{array}{l}\text { İşlem görmek üzere havale edilen evrakın kayıt bilgisinin yer aldı̆̆ı defter; karşılıklı } \\
\text { iki sayfanın tek sayfa addedildiği ve elli sayfadan mürekkep defter. Sayfanın sağı } \\
\text { gelen, sol tarafı ise giden evrak iç̧in düzenlenmiştir. Defter cildinin arkasında ait } \\
\text { olduğu yıl, cildive numara aralığı bulunmalıdır. }\end{array}$ \\
\hline
\end{tabular}




\begin{tabular}{|c|c|}
\hline Evrâk & $\begin{array}{l}\text { Bütün kurumlar tarafindan faaliyet sırasında üretilen ve adli delil olarak } \\
\text { kullanılabilecek niteliklere sahip belge. }\end{array}$ \\
\hline $\begin{array}{l}\text { Evrâk-ı atîka } \\
\text { mahzeni }\end{array}$ & $\begin{array}{l}\text { Kurum arşivi. Kurum tarihi arşivi. İdari arşivde bulunan defter ve cüzdan (dosya, } \\
\text {-büyük boy- zarf) içinde bulunan evrak, onbirinci yıl evrâk-1 atîka (kurum arşivi) } \\
\text { mahzenine transfer edilir. }\end{array}$ \\
\hline Evrâk-ı husûsîye & Kuruma gelen özel yazılar. \\
\hline Evrâk-ı resmîye & Kamu kurumu tarafından faaliyet sırasında üretilen belge. \\
\hline Evrâk-ı sâdıra & Giden evrak. \\
\hline Evrâk-ı vâride & Gelen evrak. \\
\hline Evrâk müdîrî & $\begin{array}{l}\text { Arşiv şefi. Arşive teslim edilen evrakın düzenlenmesinden ve teslim alacağı evrakın } \\
\text { tamlık/bütünlük kontrolünü yapan sorumlu. }\end{array}$ \\
\hline $\begin{array}{l}\text { Evrak müdîrî } \\
\text { muâvini }\end{array}$ & Arşiv şefi yardımcısı. Arşive teslim edilen evrakın düzenlenmesinden sorumludur. \\
\hline Evrâk taleb pusulası & Evrakın kurum personeli tarafından arşivden talep edildiği matbu form. \\
\hline $\begin{array}{l}\text { Evrâk taleb pusulası } \\
\text { dipkoçanı }\end{array}$ & Evrak talep formunun dip kısmı. \\
\hline Fihrist defteri & $\begin{array}{l}\text { Evrakın kendine ait numaraları bulabilmek için düzenlenen defter. Rakamlar sıra ile } \\
\text { birden itibaren matbu olarak defter sayfalarına basılıdır. }\end{array}$ \\
\hline Gömlek & $\begin{array}{l}\text { Cüz; iki kapaklı mukavva, ikiye kırılmış ve içine aynı işlem grubuna ait evrakın } \\
\text { konulduğu kartondan kalın kâğıt. }\end{array}$ \\
\hline Havâle & $\begin{array}{l}\text { Evrakın, işlem görmek üzere kurum içinde bir daireye veya kurum dışına } \\
\text { gönderilmesi. }\end{array}$ \\
\hline Heyet-i tahrîrîye & Genel yazışma kuralları (yazışma bilgisi). \\
\hline Hıfz-ı evrâk & $\begin{array}{l}\text { Kurumsal faaliyetlere faaliyetler sırasında üretilen ve kurumsal işlemler neticesinde } \\
\text { gelen evrakın her türlü etkenden korunması. }\end{array}$ \\
\hline Hülâsa memûru & $\begin{array}{l}\text { Evrakın özetini hazırlayan memur. Kâğıdın üst kısmındaki özetleri kontrol eder, özet } \\
\text { yoksa yazar. }\end{array}$ \\
\hline $\begin{array}{l}\text { Husûsî dosya } \\
\text { muâmelâtı }\end{array}$ & Şubelerde dosyaların işlem görmesi. \\
\hline Husûsî evrâk & Kişiye özel evrak. \\
\hline Husûsî numara & Evrakın daireyi/şubeyi/kısmı temsilen aldığı kayıt numarası. \\
\hline Hüviyet-i resmî & Resmi kimlik. Evraka özel verilen numaralar. \\
\hline İdâre & Yerel kamu hizmeti görmek üzere faaliyet gösteren kamu kurumu, belediye. \\
\hline İki sütunlu evrâk & $\begin{array}{l}\text { Bir kâğıdın herhangi bir yerinden bir çizgi ile veya ortadan kırılarak oluşturulan iki } \\
\text { sütunlu kâğıt. }\end{array}$ \\
\hline İstidâ & Dilekçe, arzuhal. \\
\hline Kâğıd & $\begin{array}{l}\text { Kurumsal faaliyetin yazılmak, çizilmek ve resmetmek suretiyle üzerine kaydedildiği } \\
\text { temel bilgi taşıyıcısı. }\end{array}$ \\
\hline Kâğıdı yapıștırmak & $\begin{array}{l}\text { Aynı muameleye ait bütün evrakın dosya şeklinde ve arka arkaya bir arada tutulması } \\
\text { yerine, kronolojik olarak alt alta yapıştırılması işlemi. }\end{array}$ \\
\hline Kalem-i mahsûs & Özel kalem. \\
\hline Kâtib & Evrakın yazı işleri ve diğer bürolarda hazırlanmasından sorumlu görevli. \\
\hline
\end{tabular}




\begin{tabular}{|c|c|}
\hline Kayd-ı husûsî & Evrakın büro ve kısımlarda kayıt altına alınması, kayıt işlemlerinin yapılması. \\
\hline Kayd-ı muâmele & İşlemin kayıt altına alınması, kayıt işlemlerinin gerçekleştirilmesi. \\
\hline Kayd-ı umûmî & Gelen ve giden evrakın kayıt işlemlerinin yapıldığı ofis. \\
\hline $\begin{array}{l}\text { Kayd-ı umûmî } \\
\text { defteri }\end{array}$ & Genel kayıt işlemlerinin üzerine kaydedildiği defter. \\
\hline $\begin{array}{l}\text { Kayd-ı umûmî } \\
\text { muâmelâtı }\end{array}$ & Genel kayıt işlemleri, gelen ve giden evrakın kayıt işlemlerinin yapılması. \\
\hline Kayd/Kayıd & $\begin{array}{l}\text { 1) İdari, ticari, özel ve şahsi biçimde icra edilen bütün faaliyetlere ilişkin evrakın } \\
\text { kurumsal olarak kayıt işlemlerinin yapılması, kayıt altına alınması; 2) belge, evrak. }\end{array}$ \\
\hline Kayıd memûru & $\begin{array}{l}\text { Evrakın kayıt işlemlerini gerçekleştiren memur. Zeki ve muamelat hakkında kesin } \\
\text { bilgisi olması gerekir. }\end{array}$ \\
\hline Kisım & Yerel kamu hizmeti gören kamu kurumunun üçüncü alt derece idari birimi. \\
\hline Kitâbet-i umûmîye & Genel yazışma. \\
\hline Lâyiha & $\begin{array}{l}\text { Herhangi bir konuda bir görüşü dile getiren yazı; tasarı. "Muâmelât-1 Kuyûdîyede } \\
\text { Islâhât Lâyihası". }\end{array}$ \\
\hline Mahrem evrâk & Gizli evrak. \\
\hline Mahzen-i evrâk & $\begin{array}{l}\text { Birim arşivi. Birim faaliyetleri sonucunda üretilen evrakın transfer edildiği birim } \\
\text { arşivi. }\end{array}$ \\
\hline $\begin{array}{l}\text { Mahzen-i evrâk } \\
\text { memûru }\end{array}$ & Arşiv memuru, arşiv çalışanı, arşivci. \\
\hline $\begin{array}{l}\text { Mahzen-i evrâk } \\
\text { mukayyidi }\end{array}$ & Birim arşivine evrak teslimi işlemlerini düzenleyen kâtip. \\
\hline Melfûfât kaydı & Belge eklerinin nelerden ibaret olduğunun defterlere yazılması. \\
\hline Memûr & $\begin{array}{l}\text { Yerel kamu hizmeti görmek üzere istihdam edilen kamu görevlisi. İstanbul } \\
\text { Belediyesinin memurları }\end{array}$ \\
\hline Muâmele-i resmîye & Resmi işlem, resmi yazışma. \\
\hline Muâvene defteri & Evrakın aranmasında kullanılan yardımcı sorgulama/araştırma aracı. \\
\hline Mukayyid & Kayıt altına alan, kâtip, memur. \\
\hline Mukayyid-i umûmî & Genel kayıt bürosu kâtibi, memuru. \\
\hline Müdîr & Yazı işleri şubesi yetkilisi. \\
\hline Mühür & $\begin{array}{l}\text { Üzerinde kurum adının ya da sanının tersine kazılı bulunduğu araç, damga; bu araç } \\
\text { mürekkeplenerek basılan ve imza yerine geçen ad. }\end{array}$ \\
\hline Müzekkire & Bir iş için, herhangi bir üst makama yazılan resmi yazı. \\
\hline Nâzır & Kurum dairesinin yöneticisi. \\
\hline Numara pusulası & $\begin{array}{l}\text { Özel kurum ve şahsa ait evrakın ilgili büro tarafından teslim alındığını ve kayıt } \\
\text { numarasının verildiğini beyan eder belge. }\end{array}$ \\
\hline Rapor & Her hangi bir konu ya da olayla ilgili inceleme sonucunu tespit ederek bildiren yazı. \\
\hline Ruhsat & Faaliyete geçecek olan bir işyerinin açılması için alınan resmi izin belgesi. \\
\hline Sâbit mürekkeb & Silgi ile silinmeyen kalem. Dolmakalem, tükenmez kalem. \\
\hline Sâhib-i istidâ & Dilekçe sahibi, arzuhal sahibi. \\
\hline
\end{tabular}




\begin{tabular}{|c|c|}
\hline Sayfa numarası & $\begin{array}{l}\text { Defter ve ikiye kırılmış evrak ile oluşturulan çok sayfalı ünitelerin her bir sayfası için } \\
\text { küçükten büyüğe sıralı şekilde verilen numaralama. }\end{array}$ \\
\hline Şehremâneti & İstanbul Belediyesi/Şehremaneti \\
\hline Şehremîni & (İstanbul) belediye başkanı \\
\hline Şehremîni muâvini & (İstanbul) belediye başkanı yardımcısı. \\
\hline Şûbe & $\begin{array}{l}\text { Yerel kamu hizmeti gören kamu kurumunun ikinci dereceden alt idari birimi; kurum } \\
\text { ana binasının uzağında kurum adına faaliyet gösteren idari birim. İstanbul Belediyesi } \\
\text { Kadıköy Şubesi. }\end{array}$ \\
\hline Şûbe âmiri & Kurum ikinci kademe idari birim yöneticisi. \\
\hline Şûbe müdîri & Kurum ikinci kademe idari birim yöneticisi. \\
\hline Şûbe fihrist defteri & $\begin{array}{l}\text { Şubelere ait evrakın kendine ait numaralarını bulabilmek için düzenlenen ve rakamlar } \\
\text { sıra ile birden itibaren matbu olarak düzenlenmiş olan defter. }\end{array}$ \\
\hline Şûbe kayıd defteri & $\begin{array}{l}\text { Şubelere ait kayıt defteri. Sağ tarafı gelen ve sol tarafı giden evrak için düzenlenmiş } \\
\text { defter. }\end{array}$ \\
\hline Şûbe mukayyidi & Şube kâtibi, şube memuru \\
\hline Şûbe müdîri & Kurum ikinci kademe idari birim yöneticisi. \\
\hline Taharrî defteri & Evrakın çıktığı büroya ve ismine göre kaydedildiği defter. \\
\hline Tahrîrî-i havâle & Evrakın havalesi için yazışma. \\
\hline Takım & Şubelerin her birine ait muamelatın bütünü; ana seri. \\
\hline Tasdîk & Evrakın yetkili görevli tarafından onaylanması. \\
\hline Tashîh & Evrak üzerinde yapılan düzeltme. \\
\hline Tasnîf-i evrâk & $\begin{array}{l}\text { Kurumlar tarafindan üretilen evrakın sorumlu memurlar tarafindan belli kurallara göre } \\
\text { düzenlenmesi. }\end{array}$ \\
\hline Tasnîf cüzü & Evrakın içine konulduğu dosya. \\
\hline Tedkîk & Evrakın kurum içinde nerede olduğunun araştırılması. \\
\hline $\begin{array}{l}\text { Tek kâğıd üstüne } \\
\text { yazmak }\end{array}$ & $\begin{array}{l}\text { Evraka ait bütün işlem notlarının ayrı kâğıtlar yerine tek bir kâğı üzerine derkenar } \\
\text { (yan notlar) şeklinde yazılması. }\end{array}$ \\
\hline Teslîm defteri & Evrakın ilgili bürosuna teslim edildiğini kayıt altına alan defter. \\
\hline Tevzi’ memûru & Evrakın dağıtımını yapan memur; dağıtım memuru. \\
\hline Tezkîre & $\begin{array}{l}\text { Kalemler (bürolar) ve kişiler adına yazılmış özet belgelerin diplomatik bilimindeki } \\
\text { genel adı. }\end{array}$ \\
\hline Tomar & $\begin{array}{l}\text { Aynı muameleye ait ve alt alta yapıştırılmış evrakın dürülmesiyle oluşturulan yığın, } \\
\text { kütle. }\end{array}$ \\
\hline Umûmî numara & Evrakın kurumu temsilen aldığı kayıt numarası. \\
\hline Umûr-ı resmîye & Kamu kurumu tarafından yürütülen faaliyetler. \\
\hline Usûl & Evrakın kayıt, korunması, düzenlenmesi konularında geliştirilen yöntem. \\
\hline Usûl-i kayıd & Evrakın kurum tarafından kayıt altına alınması için geliştirilmiş yöntem. \\
\hline Usûl-i tasnîf & $\begin{array}{l}\text { Tasnif/düzenleme yöntemi/metodu. Evrakın erişiminin kolaylaştırılması ve belli bir } \\
\text { düzene kavuşturulması amacıyla geliştirilmiş yöntem. }\end{array}$ \\
\hline Yazıhâne & Yazışmaların yürütüldüğü ofis, yazı işleri bürosu. \\
\hline
\end{tabular}


